\section{Ervin Dubrović}

Muzej grada Rijeke / Rijeka City Museum

Muzejski trg 1/I, Rijeka

ervin.dubrovic@muzej-rijeka.hr

Prethodno priopćenje / Preliminary communication

UDK / UDC: 75 Littrow, L. von

DOI: $10.17685 /$ Peristil.59.7

12. 9. 2016.

\title{
Leontine Littrow, slikarica s kraja 19. i početka 20. stoljeća
}

Ključne riječi: Leontine Littrow, slikarstvo, plenerizam, impresionizam, Austrija, Hrvatska Keywords: Leontine Littrow, painting, plein air, Impressionism, Austria, Croatia

Leontine (Leo, Lea, Leonie) von Littrow (Trst, 1855. - Opatija, 1925.) kći je mornaričkog časnika, riječkoga lučkog kapetana i pomorskog inspektora, koja je od djetinjstva do kraja života živjela u Rijeci i Opatiji. Slikanje uči kod pariškog slikara Jeana d'Alheima, a u gotovo pola stoljeća umjetničkog djelovanja prolazi razvoj od početničkog »romantizma« do plenerizma $i$ impresionizma te, na kraju, do ekspresionog slikanja primorskih i dalmatinskih krajolika. Od 1880. godine izlaže na brojnim izložbama u Beču, Münchenu, Budimpešti, Pragu, Londonu, Opatiji, Klagenfurtu, Salzburgu, Černivcima, Wrocławu, Kopru $i$ Rijeci, a naročit uspjeh postiže na samostalnim izložbama u Londonu od 1896. do 1904. godine.

\section{Pristup}

Leontine Littrow koja se potpisuje isključivo kao Leo Littrow, kako je navedena i u brojnim katalozima i novinskim napisima, slikarica je kvarnerskih i dalmatinskih marina, pergola, vrtova i parkova. Živjela je u Rijeci i Opatiji, a izlagala u Beču, Münchenu i Londonu krajem 19. i početkom 20. stoljeća. Slike joj se i danas često pojavljuju u Beču u aukcijskim kućama Dorotheum, Im Kinsky i u drugim galerijama, no i oni koji trguju njezinim slikama i poznaju njezin rad, o njoj samoj još uvijek znaju malo te redovito navode čak i krive godine njezina rođenja i smrti. Na internetskim stranicama bečkih aukcijskih kuća i trgovaca umjetninama pojavljuju se desetine njezinih slika, mahom ulja na platnu, no nitko još do danas nije pokušao sastaviti opsežniju biografiju te dati sustavan pregled njezina rada i umjetničkog razvoja, od prvih do posljednjih pojavljivanja na umjetničkoj sceni. Iako je izlagala na brojnim izložbama i imala više samostalnih nastupa, dosad nije sastavljen ni popis njezinih izložbi i katalog njezinih radova. Dakako, bez opsežnih istraživanja nije bila moguća ni temeljita kritička prosudba njezina djela, kojoj se pristupilo zahvaljujući inicijativi bečkih galerista vezano uz priređivanje izložbe i monografije. ${ }^{1}$

Istraživanje slikarskog opusa Leontine Littrow dolazi upravo u trenutku kada je započela sustavna kritička obrada bečkog kruga plenerista i impresionista objavljivanjem umjetničkih monografija bečkih slikara krajolika s kraja 19. i početka 20. stoljeća, Marije Egner, Theodora von Hörmanna i Roberta Russa, uz već poznate opuse Emila Jakoba Schindlera i Carla Molla. ${ }^{2}$

\section{Podrijetlo i obitelj}

Leontine von Littrow (ime se navodi u raznim inačicama, Leo, Lea ili Leonie »von« ili »de« Littrow ili samo Leo Littrow) pripada dvjema uglednim obiteljima, Littrow i Barry, koje su 
obilježile njezin umjetnički život. Littrowljevi vuku podrijetlo iz Estonije, a Barryjevi na Jadran dolaze iz Engleske. ${ }^{3}$

Leontinin stric Karl Ludwig nastavlja očev rad u bečkom opservatoriju, a njegova žena, spisateljica Augusta, već prije polovine 19. stoljeća zaštitnica je mladih umjetnika koji obilaze njezin umjetnički salon i toliko omiljena da joj Josef Danhauser, jedan od privrženika, slika portret s mužem, a čuveni komediograf Franz Grillparzer posvećuje joj komediju nazvanu Astronomova žena. ${ }^{4}$ Salon gospođe Littrow pohodi i Iso Kršnjavi, tadašnji student bečke Akademije likovnih umjetnosti i budući hrvatski ministar bogoštovlja i nastave. Upravo on, u već poodmaklim godinama svoga života, izjavljuje da su mu ta druženja značila mnogo više od druženja s kolegama. ${ }^{5}$

Mornarički časnik, pisac i pjesnik Heinrich von Littrow (Beč, 1820. - Opatija, 1895.) godine 1863. imenovan je za lučkog kapetana u Dubrovniku, pa u Senju i onda, 1867., u Rijeci, gdje poslije postaje pomorski inspektor. ${ }^{6}$ Mirovinu dočekuje 1880. u činu kapetana bojnog broda. Sve do 1889. zadržava dužnost člana ispitnog povjerenstva na nautičkoj školi te sudjeluje u ispitima za pomorskog kapetana. ${ }^{7}$ Von Littrow je također sklon književnosti i slikarstvu. O tome svjedoče i sačuvana panorama Senja (Pomorski i povijesni muzej Hrvatskog primorja, Rijeka) i sjećanja Ise Kršnjavoga koji se u mladosti za ljetnih praznika 1867. nakratko zatječe u Rijeci i poučava slikarstvu ovdašnjega lučkog kapetana. ${ }^{8}$ Kažu da se "nije odvajao od štafelaja k kao i da je oduševljenje prenio na svoju kćer Leontine. Svoje je slike rado donirao, među inima i gradskoj ubožnici kojoj je poklonio ulje na platnu Snježna mećava i Jaslice naslikane na metalnoj ploči. ${ }^{9}$

Ni obitelj Leontinine majke, Barry, ne zaostaje za obitelji Littrow. Trgovaci novčar Charles Frisby Barry (1790.-1832.) vjerojatno je irskog podrijetla, no rodom iz Hitchina u Hertfordshireu u blizini Londona i anglikanac, oženjen Matildom, rođ. Laurie (London, 1804. - Pula, 1873.). Njih dvoje prvo dolaze u Genovu, a potom se oko 1830. nastanjuju u Trstu. ${ }^{10}$ Barryjevi se brzo prilagođavaju ovdašnjim prilikama i više ih ulazi u službu Austrijske ratne mornarice. ${ }^{11}$ Neki su članovi obitelji Barry također više godina proživjeli u Rijeci. Ovamo su dolazili i više godina ovdje boravili svi oni koji su bili pitomci Mornaričke akademije. Tako su, barem za vrijeme školovanja, Barryjevi bili u blizini Littrowljeve male obitelji i viđali se sa svojim rođacima.

Obiteljski život Heinricha von Littrowa obilježen je rođenjem petero djece, no isto tako i preranim smrtima članova najuže obitelji. Već početkom šezdesetih, još u Trstu umire njegova žena Carolina Fanny (1861. ili 1862.), a poslije i dvoje djece, najstarija kći Matilde (rođena 1848.) i jedini sin, Joseph Johann (1853.-1866./67.). Kapetan Littrow nastavlja živjeti zajedno s kćerima Alice Gabrielle (Trst, 1851. - Beč, 1901.), Helene (Elena; Trst, 1861. - Opatija, 1922.) i Camilom Leontinom. ${ }^{12}$ Djetinjstvo Littrowljevih kćeri obilježeno je i očevim selidbama. Nakon Trsta nekoliko godina žive u Dubrovniku i Senju, gdje im je otac namješten kao lučki kapetan, a onda 1867. dolaze u Rijeku i odrastaju u kozmopolitskoj klimi grada koji je upravo u velikom usponu. I Camila Leontine (Trst, 17. ožujka 1856. Opatija, 11. svibnja 1925.) rođena je i odrasla u primorskom i pomorskom okruženju. ${ }^{13}$

Iako daleko od Beča, okružena mahom Talijanima i Hrvatima, Leontine odrasta u krugu obitelji njemačkih časnika i britanskih industrijalaca i inženjera. Među profesorima i pitomcima Mornaričke akademije u Rijeci većina je Nijemaca koji se okupljaju u Klubu prirodnih znanosti (Naturwissenschaftliches Club) te drže popularna predavanja, mahom o novim znanstvenim dostignućima i tehničkim izumima. Uz više stotina Nijemaca i Mađara, u to se doba u Rijeci nastanila i koja stotina Engleza, mahom inženjera i tehničara u riječkim tvornicama, naročito u Whiteheadovoj tvornici torpeda. Život u Rijeci obilježen je očevim aktivnostima i društvenim odnosima s vodećim obiteljima, poput vlasnika tvornice torpeda Whiteheada i njegova zeta grofa Hoyosa, britanskog konzula Fabera, obitelji vlasnika tvornice papira Meyniera te vlasnika tvornice kože Simonića. ${ }^{14}$

O Leontininu najranijem školovanju nemamo nikakvih vijesti, no može se pretpostaviti da su joj osnovno obrazovanje, možda, pružile časne sestre (jednu su takvu djevojačku školu držale benediktinke) te da je nadalje učila u kakvu privatnu zavodu za djevojčice. Ni javno gimnazijsko a ni akademsko obrazovanje u to doba djevojkama još nije bilo dostupno.

Leontine je već tridesetogodišnjakinja kada krajem osamdesetih obitelj seli u Opatiju koja tada upravo doživljava velik preobražaj. ${ }^{15}$ Donedavno još neznatno mjesto pored Voloskog, nastanjeno ribarima i pomorcima, $\mathrm{s}$ crkvom sv. Jakova i davno ukinutom benediktinskom opatijom, $s$ malim okolnim zaselcima na padinama podalje od mora, $s$ raštrkanim kućicama i tek ponekom gospodskom vilom uz obalu, ubrzano raste. Upravo se tada grade prvi hoteli, $Q u$ arnero (1884.) i Kronprinzessin Stephanie (1885.), te razvija klimatsko lječilište i mondeno odmaralište. ${ }^{16}$

Obitelj Littrow, otac i tri neudane kćeri, početkom devedesetih nastanjuju se u tek sagrađenoj Villi Rusticani (1891.). ${ }^{17}$ Uz vilu je nešto kasnije izgrađen i atelijer koji je nakon samo nekoliko godina bitno preuređen te se počinje nazivati Villa Littrow. Katkad se obje zgrade zajedno nazivaju »Villa Rusticana - Littrow«. Otac se već krajem osamdesetih uključuje u društveni rad te potiče uređenje i poljepšavanje Opatije. Godine 1887. pridružuje se osnivačima Yacht kluba, a 1888. postaje upravitelj vojnog odmarališta. Za zasluge u uređenju grada Opatijci mu se poslije odužuju spomenpločom s njegovim portretom u reljefu. ${ }^{18}$

Leontine se također uključuje u društveni život mondenog lječilišta i zimovališta. Zajedno s malom skupinom umjetnika koji ovdje stalno ili povremeno obitavaju, uključuje se u razne priredbe i događanja, poput tematskih i kostimiranih balova. Isto tako pozivaju je i da donira svoje radove za dobrotvorne priredbe. U jednoj takvoj prigodi 
1893. organizirana je i prva Leontinina samostalna izložba u Villi Angiolini. ${ }^{19}$ Na prijelazu stoljeća aktivna je u okupljanju opatijskoga umjetničkog udruženja nazvanog Umjetnička kolonija (Künstler-Colonie »Abbazia«) koje od 1900. do 1902. priređuje tri ambiciozne izložbe. Leontine se posebno uključuje u izgradnju umjetničkog paviljona, lagane drvene, dobro ostakljene građevine koju zbog jednostavna izgleda i nevelikih dimenzija katkad nazivaju i »kiosk«. U vezi s izgradnjom šalje dopise općini Volosko. ${ }^{20}$ Paviljon-kiosk podignut je u blizini glavne ulice Reichstrasse (danas Ulica maršala Tita), na istočnom rubu središnjeg dijela grada, Slatine.

Od osamdesetih nadalje Leontinin je životni i umjetnički put već jasno zacrtan. Ne udaje se i ne zasniva vlastitu obitelj nego zajedno s ocem i sestrama živi u Opatiji i posve se posvećuje slikarstvu. Redovito obilazi i ugledne riječke obitelji, među kojima i groficu Alice Hoyos, kćer tvorničara Whiteheada, koja u svojoj zbirci ima više njezinih slika. ${ }^{21}$

Leontine ima još jednu strast: prikuplja predmete "narodne umjetnosti« (Volkskunde) koji su već potkraj 19. stoljeća u bečkim krugovima postali naročito omiljeni. Istra i Dalmacija postaju zanimljive kao zemlje egzotičnog krajolika i još uvijek neiskvarene pučke kulture. I ona prikuplja folklorne predmete, rezbarene drvene škrinje, keramičko posuđe, bakrene lonce i zdjele. Nakon velike izložbe austrijske narodne umjetnosti 1905., u tek osnovanom Austrijskom etnografskom muzeju u Beču, prikazana je i dalmatinska pučka kultura. Ubrzo nakon izložbe, osnivač Muzeja, jedan od pionira austrijske etnologije i skupljač istarske i dalmatinske građe, Michael Haberlant odlazi u novi pohod u Istru i Dalmaciju, te stiže i do Opatije. Iako građu najviše prikuplja u unutrašnjosti Istre, također odlazi i u najbližu okolicu Opatije i u Lovran. ${ }^{22}$

Zbog svojih redovitih južnih putovanja i neprolazne strasti za primorske i dalmatinske teme Leontine postaje suradnica austrijskih istraživača dalmatinskog folklora. ${ }^{23}$ Više predmeta iz njezine zbirke poslužilo je za ilustriranje ogledne knjige o pučkoj umjetnosti u Dalmaciji, objavljene 1911. u Beču. ${ }^{24} \mathrm{U}$ istoj su knjizi objavljeni i brojni predmeti iz zbirke »narodne umjetnosti« Istre i Dalmacije što ih je prikupila agilna barunica Stephanie Rubido-Zichy (1857.-1929.), Leontinina dobra poznanica, ljubiteljica umjetnosti te organizatorica opatijskih kulturnih i humanitarnih događanja i zabava. ${ }^{25}$ Barunica je, također, u Casino des Etrangers u travnju 1912. organizirala izložbu opatijskih umjetnika na kojoj sudjeluje i Leontine. Na toj su izložbi bili izloženi i istarski i dalmatinski predmeti folklorne umjetnosti. ${ }^{26}$

\section{Slikarski počeci i učitelj Jean d'Alheim}

Leontine Littrow prvu je pouku iz crtanja mogla dobiti u djevojačkoj školi, a ne treba zanemariti ni očev poticaj. Jedan je od prvih slikara koje je vidjela na djelu bio mladi student Iso Kršnjavi. Imala ga je vjerojatno prilike gledati dok je ljeti 1867. poučavao njezina oca. O njezinu likovnom obrazovanju postoje uopćene tvrdnje da je, osim u Rijeci i Opatiji, živjela i u Beču, te da je učila u Parizu i Münchenu. ${ }^{27}$ Jedino je sigurno da joj pouku pruža pariški slikar Jean d’Alheim (Kursk, 1832. - Pariz, 1894.). ${ }^{28}$ Ovom je rusko-francuskom slikaru djed prebjegao u Rusiju 1792., poslije Revolucije. Jean d'Alheim izdanak je francusko-ruske plemićke obitelji, koji nakon ženidbe napušta Rusiju i odlazi u Pariz. ${ }^{29}$ D’Alheim putuje raznim krajevima te slika raznovrsne predjele i gradove, sive sjevernjačke i slikovite alpske i mediteranske prizore. Daje i slikarsku pouku pa je vjerojatno poučavao i svoju ženu. ${ }^{30}$ Tvrdnja da je Leontine "učenica Jeana d'Alheima u Parizu « znači da ju je učio slikati, no to baš nije moralo biti u Parizu. ${ }^{31} \mathrm{O}$ njezinu odlasku u Pariz ne znamo ništa, a o njihovim susretima u Veneciji možemo nagađati na osnovi sličnih motiva iz venecijanske lagune koje rade otprilike u isto vrijeme. Mogao ju je poučavati i u Rijeci gdje je također boravio u vrijeme njezinih početaka, 1881., i naslikao Panoramu Rijeke s Trsata. ${ }^{32}$ Pored ruskih i sjevernjačkih krajolika, francuskih i talijanskih marina, D'Alheim slika i u Hrvatskom primorju i Dalmaciji. S putovanja što ga poduzima početkom osamdesetih poznate su mu slike Rijeke i Raba te Dubrovnika. ${ }^{33}$

Upravo tijekom osamdesetih D'Alheim prolazi razvoj od tamnoga atelijerskog slikanja do svijetlih i prozračnih plenerističkih slika. O njegovu razvoju možemo zaključivati na osnovi usporedbe Panorame Rijeke s Trsata što ju je naslikao oko 1880., i Pogleda s Montmartrea na Pariz koji je, sudeći po Eiffelovu tornju koji se nazire u daljini, naslikao desetak godina kasnije, oko 1890. ${ }^{34}$ Panorama Rijeke s uzvisine Trsatskog kaštela naslikana je u naglašenom kontrastu između Kaštela u dubokoj sjeni, u prednjem planu, i grada pred kojim se širi zaljev, a pogled zaokružuju otoci i Učka u pozadini. Nasuprot zasjenjenju terase Kaštela, veduta Rijeke doima se naročito obasjana.

\section{Umjetnički razvoj}

Većinu svojih radova Leontine Littrow signira, katkad punim imenom, katkad samo inicijalima, no nikad ih ne datira. Njezin umjetnički razvoj, od početka osamdesetih godina 19. pa sve do početka dvadesetih godina 20. stoljeća, možemo pratiti izravnim uvidom u njezine slike, oslanjajući se na nazive $u$ katalozima izložbi i na one malobrojne slike kojima se pouzdano zna točno vrijeme nastanka, kao i na kritičke prikaze. ${ }^{35}$

Početkom osamdesetih slika u Rijeci (Fiumara), a poslije najčešće u bližoj okolici Opatije, u Voloskom, Iki i Lovranu. Potom odlazi u udaljenija primorska mjesta, u Dragu, Mo- 


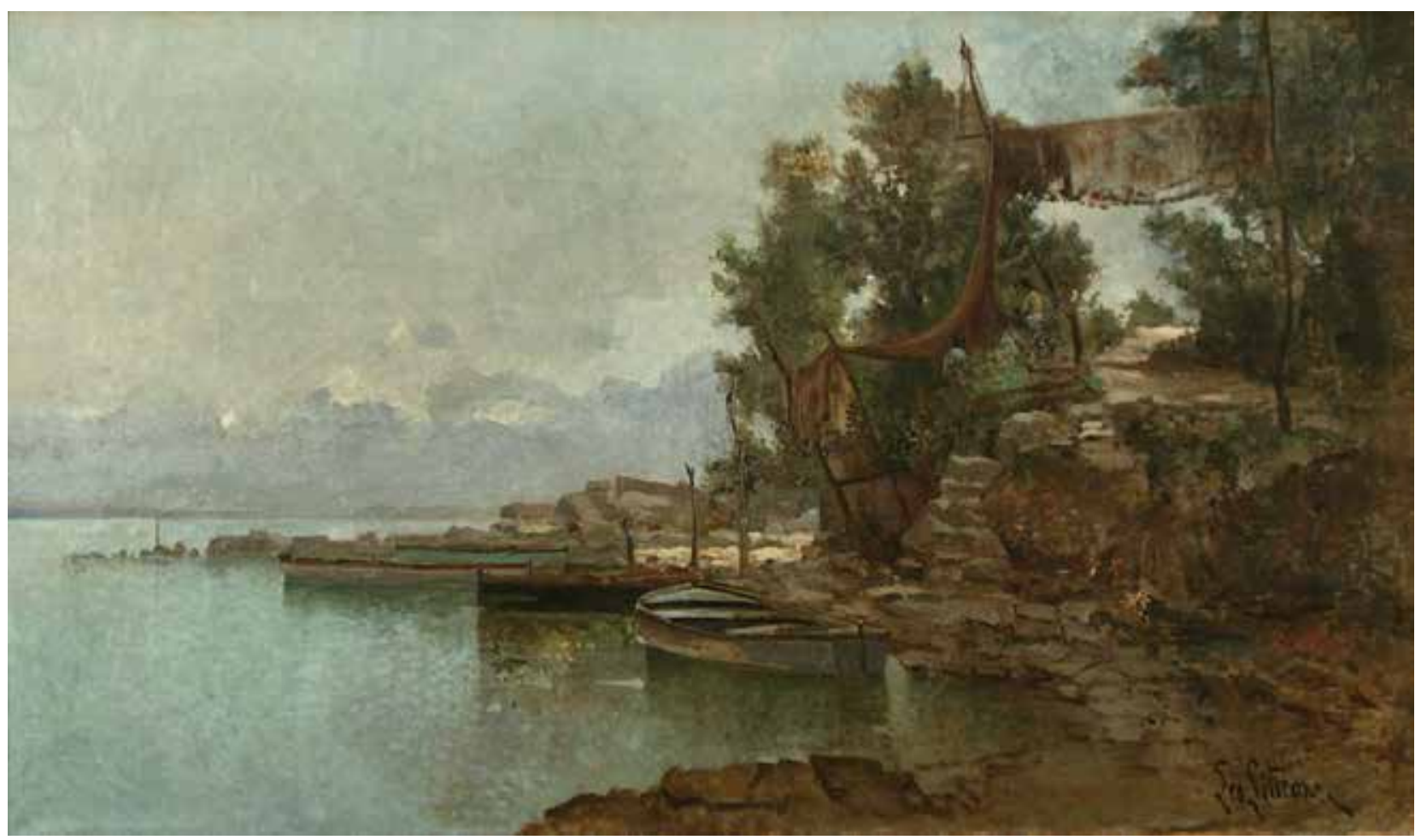

1. Leontine Littrow, Dražica, ribarska lučica u Opatiji, 1880-ih, ulje na platnu, $56 \times 94 \mathrm{~cm}$, Muzej grada Rijeke, inv. br. D-259 / Leontine Littrow, Creek, fishing harbour in Opatija, 1880s, oil on canvas, $56 \times 94 \mathrm{~cm}$, Rijeka City Museum, inv. no. D-259

šćenice i Brseč. Od ranih osamdesetih odlazi u Veneciju i obližnja mjesta i gradove, a slika i u Duinu i u Bellunu. ${ }^{36} \mathrm{Na}$ prvim izložbama izlaže gotovo isključivo venecijanske prizore, vjerojatno zato jer se njima nada polučiti veći uspjeh. $\mathrm{Na}$ izložbi u Künstlerhausu u Beču 1882. izlaže Ribarske čamce, 1883. izlaže Venecijansku ribarsku brodicu te Fiumaru, kanal s brodicama u Rijeci i Gostionicu All'Ancora u Opatiji, sljedeće 1884. u Beču izlaže U Veneciji, 1885. opet Venecijansku ribarsku brodicu, a 1886. Ribarske čamce, Ribarske brodice i Veneciju. Potom izlaže Dolce far niente, Istarsku obalu i Plažu kraj Opatije. ${ }^{37}$ Budući da je početkom osamdesetih najviše privlače ribarski motivi, slikovite brodice i jedrenjaci na pučini, britanski konzul u Rijeci George Louis Faber povjerava joj ilustriranje svoje opsežne knjige o ribarenju i ribama na Jadranu. ${ }^{38} \mathrm{U}$ knjizi je objavljeno osamnaest drvoreza izrađenih prema ilustracijama koje je nacrtala 1882 ., neposredno uoči tiskanja knjige. ${ }^{39}$ Nisu poznati izvorni radovi, no njezin pristup ipak možemo procjenjivati prema objavljenim ilustracijama. Osim Svjetionika u Premanturi, svi drugi crteži prikazuju Rijeku i okolicu - Volosko, Preluk, Bakar, Rab, otočić Sveti Marko. Crta i tipične ribarske ambijente, bragoce i male barčice u raznim okolnostima, na obali, na pučini, u ribolovu i u bijegu od bure, tunare i malo brodogradilište, kao i općenite motive uzburkanog mora, olujnog neba, kućica na stjenovitim obalama. S iznimkom panorame Rijeke i Trsata, sve su ilustracije u vezi s ribarima, ribarenjem i morem. Pomalo su romantičarski intonirane, no s podosta očita zanimanja i poznavanja ribarskih ambi- jenata i pojedinosti. Objavljeni drvorezi jedini su tragovi njezinih crtačkih sposobnosti. Leontine se nikad više nije ni pokušala predstavljati kao crtač, pa ni kada je dvadesetak godina kasnije još jednom prihvatila zadatak da izradi ilustracije za knjigu. Drugi je put umjesto crteža izradila slike $\mathrm{u}$ ulju koje su i reproducirane u boji. ${ }^{40}$

Faberovu knjigu ilustrirala je na zadanu temu, no neovisno o tome osamdesetih je godina dugo zaokupljaju život uz more i ribarski motivi. Nakon poneke rane slike Fiumare, riječkoga »mrtvog kanala«s ribarskim i trgovačkim brodicama, brzo se okreće Voloskom i Opatiji te slika tamošnje stjenovite obale i lučice, ribare u svojim barčicama na pučini i uz obalu, pokraj čamaca i mreža. ${ }^{41}$ Među prvim su joj slikama opatijska Dražica (sl. 1) i venecijanski prizori (sl. 2) što ih je naslikala početkom osamdesetih. Jedna prikazuje stjenovit zaklon i razapete mreže među stablima još neuređene opatijske obale, a druga, venecijanska, rivu i jedrenjake privezane uz obalu. ${ }^{42}$

I opatijske i venecijanske slike s početka osamdesetih imaju jednak ugođaj, sličnu kompoziciju, jednak prevladavajući zeleno-smeđi kolorit, $s$ jednako naslikanim morem i nebom. Kolorit i potezi kista ovih slika upućuju na ranu tehniku L. Littrow naučenu od D’Alheima. Površinu vode slika pastozno, kratkim, pravilno nanošenim paralelnim potezima. Nebo joj je, naprotiv, »bidermajerski« glatko, a potezi nevidljivi. U slikama iz Lagune, kojima se često i rado predstavlja na izložbama u Beču i drugdje, Venecija se najčešće i ne vidi ili se tek nazire u daljini (sl. 3). Draži su joj 


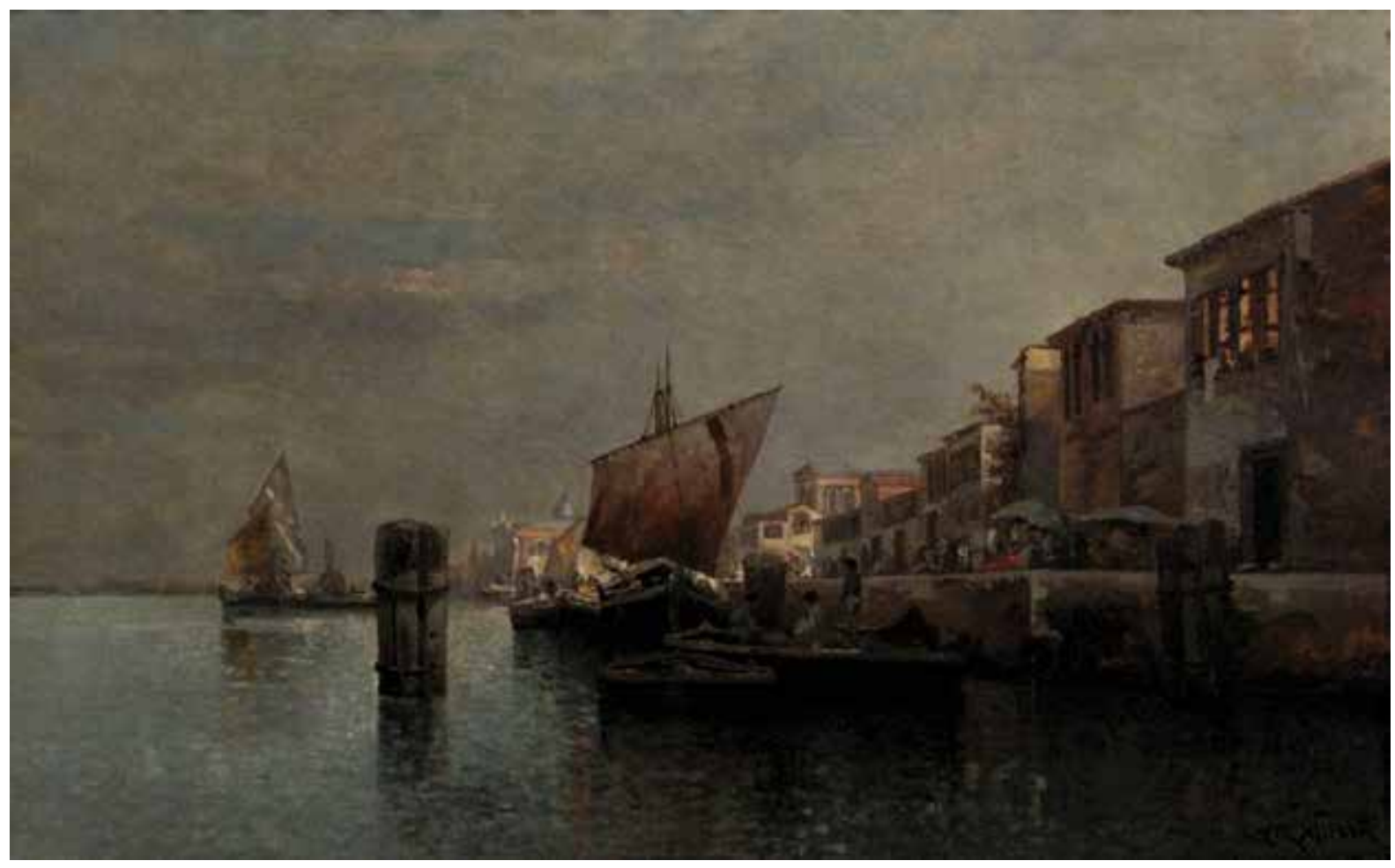

2. Leontine Littrow, Venecija, 1880-ih, ulje na platnu, $56 \times 98 \mathrm{~cm}$, Muzej grada Rijeke, inv. br. D-260 / Leontine Littrow, Venice, $1880 \mathrm{~s}$, oil on canvas, $56 \times 98 \mathrm{~cm}$, Rijeka City Museum, inv. no. D-260

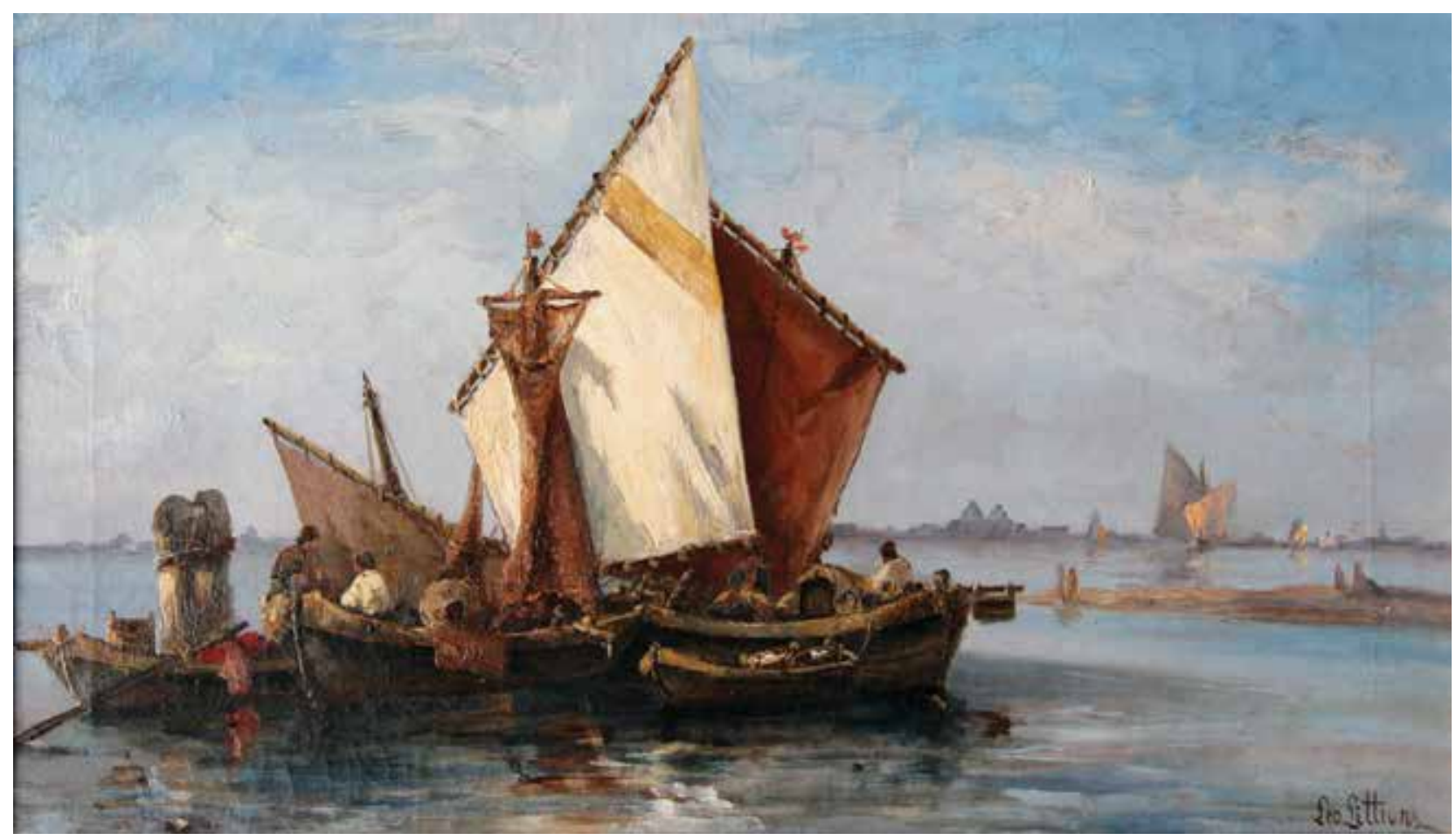

3. Leontine Littrow, Ribarske brodice u Laguni, kraj 1880-ih, ulje na platnu, 27,7 × 47,4 cm, privatno vlasništvo, Lovran / Leontine Littrow, Fishing boats in the Laguna, late 1880s, oil on canvas, $27.7 \times 47.4 \mathrm{~cm}$, private collection, Lovran

ribarski ambijenti udaljenih otočića, kućice nalik kolibama, nadstrešnice pokrivene slamom i uz njih brodice sa šarenim jedrima, mreže izvješene na slikovita sušila kao i osamljene ribarske brodice na pučini. Veneciji se i poslije često vraća. No, u njezinu su opusu najbrojnije slike kvarnerskih zakutaka. Isprava su joj najdraži motivi bliske, ribarske i težačke 


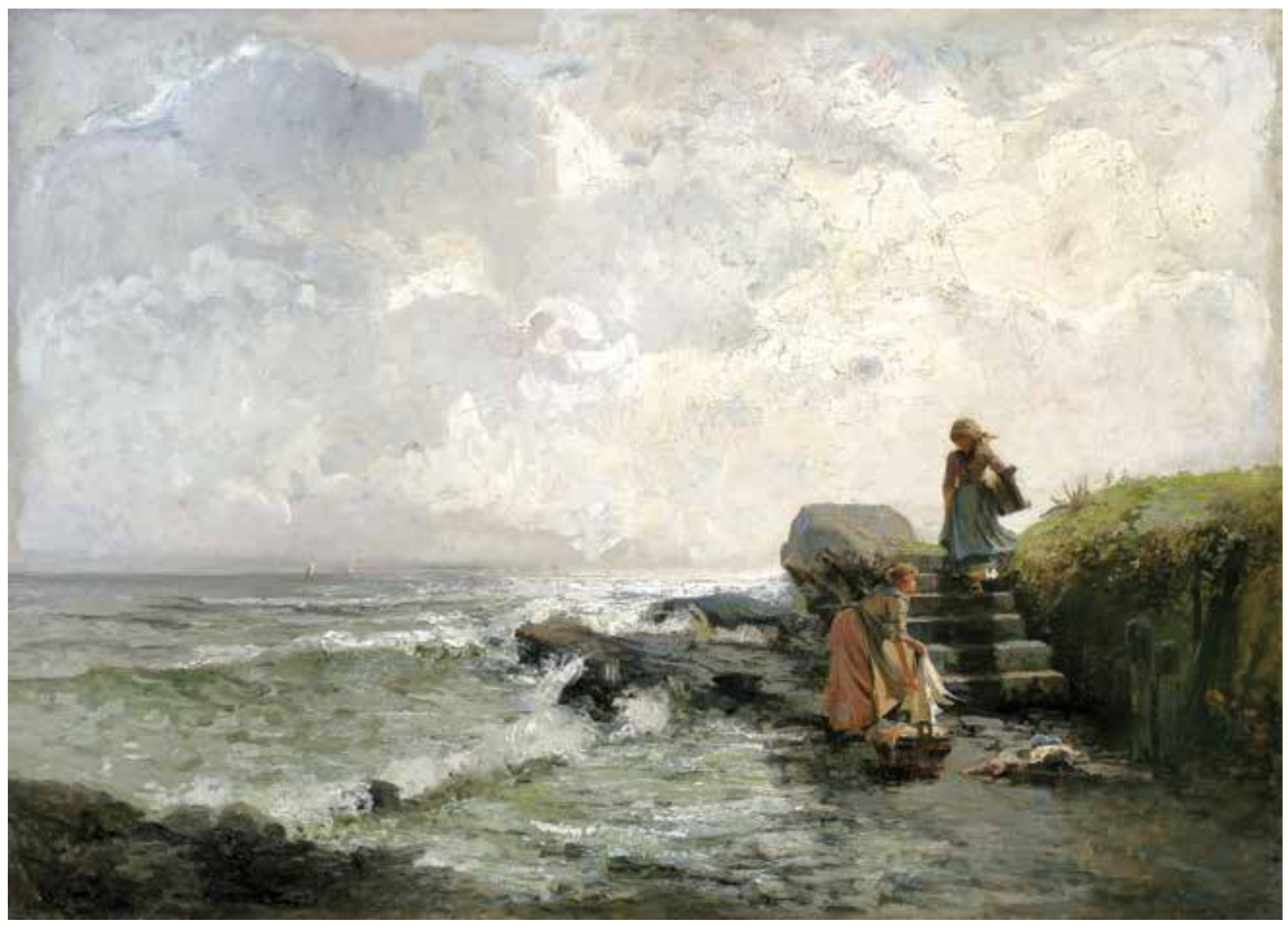

4. Leontine Littrow, Pralje na obali, kraj 1880-ih, ulje na platnu, $69 \times 96 \mathrm{~cm}$, privatno vlasništvo, Beč / Leontine Littrow, Laundresses on the shore, late 1880s, oil on canvas, $69 \times 96 \mathrm{~cm}$, private collection, Vienna

opatijske okolice, predjeli koje još ne zahvaća izgradnja hotela i vila. Stjenovite uvale i lučice sve više ispunjava likovima, ribarima i praljama, koji na neki način humaniziraju taj pomalo nepristupačan i stjenovit krajolik (sl. 4).

U to doba, osamdesetih i devedesetih godina, više austrijskih pejzažista slika Opatiju i okolicu, pa su pogodni za odmjeravanje sa slikama Leontine von Littrow. U isto vrijeme i u istom ambijentu Leopold Munsch 1880. slika Volosko romantičarskim preuveličavanjem, prema skicama i sjećanju koje je ribarski gradić toliko uvećalo da na njegovoj slici izgleda kao da je mnogo veći grad, sa zgradama podignutim na strmoj i stjenovitijoj obali. ${ }^{43}$ Gottfried Seelos slika mnogo mekše i magličastije, a njegov je niz slika opatijske obale iz 1880-ih mnogo suzdržaniji i tiši. Eugen Jettel 1890-ih slika Iku suzdržanim koloritom i s osjećajem za pojedinosti. Ovamo podosta rano dolazi i toskanski nadvojvoda Ludwig Salvator, analitičan i oštrouman promatrač, no zainteresiran za prirodu i život puka a ne za umjetnost. Svoju knjigu o Opatiji sam ilustrira crtežima stabala, biljaka, ribarskih zakutaka, obalnih kućica i barčica (1880-ih), no podosta nevješto i bez osobitih slikarskih ambicija. ${ }^{44}$ Upadljivo je da se nitko od ovih slikara ne zanima za mondeno i kupališno mjesto koje se upravo podiže u dotad gotovo pustom kra- joliku. Svi su više zaokupljeni slikovitošću okolnih mjesta, ribarskim i težačkim ambijentom, primorskim ugođajem, morem, stijenama uz obalu i velikim hrastovima koji se ovdje nadvijaju nad more. Tek poslije, na pragu novog stoljeća, pojavljuje se mnogo mlađa opatijska slikarica Stephanie Glax koja ovdašnjem društvenom životu daje autentičan likovni izraz, crtajući i slikajući prizore, za koje riječke novine kažu da su "alla Mucha«. Stephanie je najpoznatija po plakatima opatijskih događanja i ilustracijama turističkih vodiča. ${ }^{45}$

Pristupom i motivima Leontini su najbliže nešto starije bečke slikarice Marie Egner i Olga Wisinger-Florian. Marie Egner (Bad Radkersburg, 1850. - Beč, 1940.) već 1876. crta Mošćenice ugljenom na papiru, a 1877. boravi i slika u Rijeci, Iki i Lovranu. Više je crteža, akvarela i ulja na opatijskom području naslikala oko 1890.: luku u Voloskom, groblje u Voloskom, groblje u Opatiji, panoramu Brseča, te više prizora morskih hridi i zapjenjenog mora. Dolazila je i mnogo kasnije i opet slikala u Opatiji i okolici, u Voloskom i Kastvu. Naročito je privlači zapjenjeno, uzburkano more koje se razbija o stijene uz obalu (1911.).46

Leontine je naročito povezana s bečkom slikaricom Olgom Wisinger-Florian (Beč, 1844. - Grafenegg, 1926.) s kojom se druži od 1887. godine. S njome dijeli i svoj ateli- 


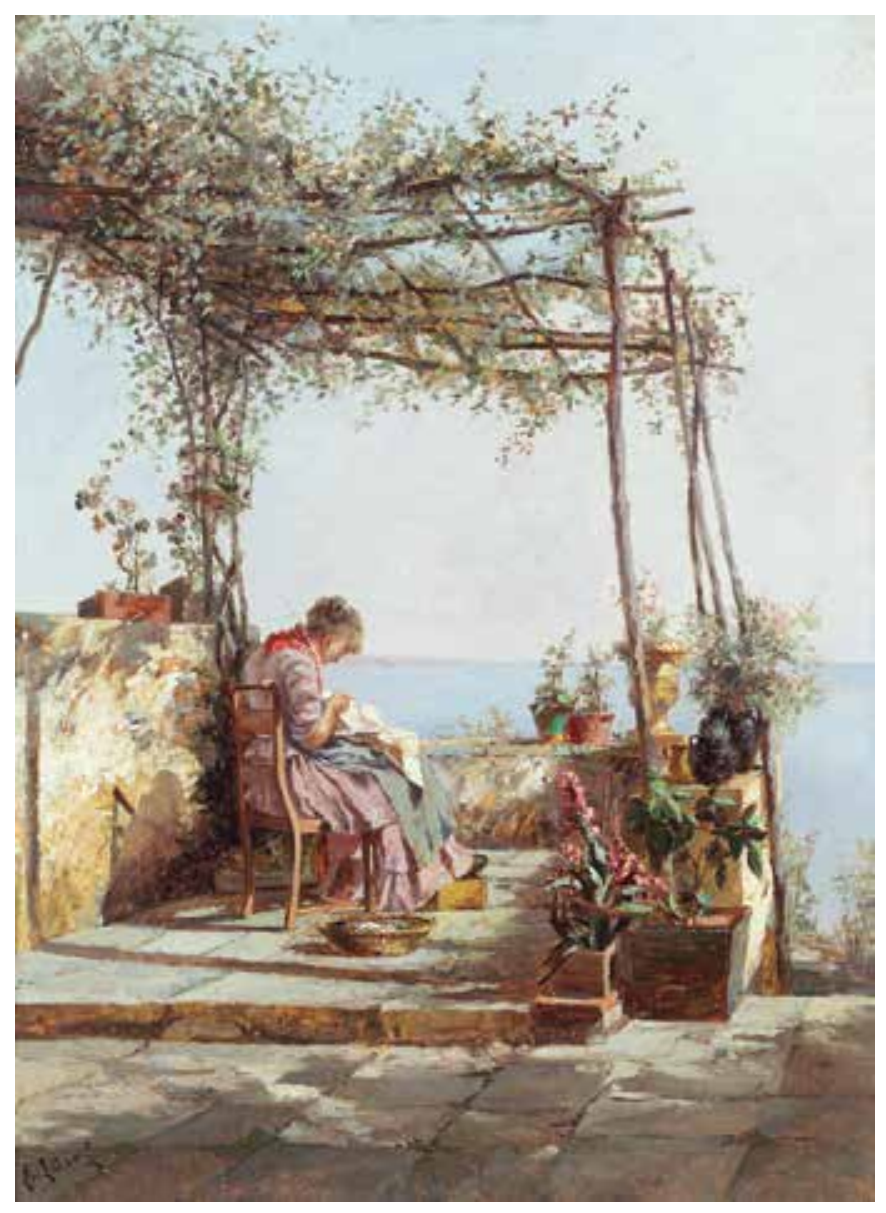

5. Leontine Littrow, Djevojka pod pergolom, oko 1890., ulje na dasci, $42 \times 30,5 \mathrm{~cm}$, privatno vlasništvo, Beč / Leontine Littrow, Girl under pergola, c. 1890, oil on panel, $42 \times 30.5 \mathrm{~cm}$, private collection, Vienna

jer, a zajedno odlaze i slikati u opatijske parkove i okolicu. Zajedno obilaze i nadvojvotkinju Klotilde, ženu nadvojvode Josipa, koja od osamdesetih godina nadalje zimske mjesece provodi u Rijeci. Olga redovito dolazi u Rijeku i Opatiju sve do 1905. godine. ${ }^{47}$

Leontine i Olga imaju više zajedničkih tema te dijele i zanimanje za iste genre-scene. Uz prizor djevojke pod pergolom zajedničke su im i slike pralja na obali mora. Ovi prizori nisu samo novi motivi u njihovim slikama nego se u njima može nazrijeti i najavu društvene osviještenosti i ženske samosvijesti koja se u Austriji rađa upravo tih godina. Filantropskom suosjećanju razvijenom u aristokratskim i građanskim krugovima, pridružuje se i pojava feminizma. Olga Wisinger-Florian jedna je od najistaknutijih feministica i dugogodišnja predsjednica bečkog Udruženja spisateljica i slikarica (Verein der Schriftsellerinnen und Künstlerinnen Wien), osnovanoga 1885. godine.

Na ranijim Leontininim slikama žene su samo sporedni likovi, one samo ispraćaju i dočekuju muževe koji odlaze i vraćaju se s ribolova. Uskoro postaju glavni protagonisti i obje prijateljice rado slikaju pralje na obali, s košarama ili pogurene nad vodom, na mjestima nalik onima na kojima Leontine prije slika ribare: uglavnom na stjenovitoj obali, katkad teško pristupačnoj, do koje se prilazi usječenim strmim stubama. Slika ih i na plaži i na ušću potoka koji se ulijeva u more. ${ }^{48}$ Potkraj osamdesetih i početkom devedesetih, umjesto tamnijih slika pralja prigušenih boja, Leontine i Olga počinju slikati svjetlije slike s motivom djevojke pod pergolom (sl. 5), koje su uzajamno još sličnije od pralja. Iako se isprva može pomišljati na socijalnu dimenziju u njezinim slikama, u kasnijem, plenerističkom razdoblju, ona posve izostaje. Naprotiv, katkad slika rutinske, već razrađene prizore, ispunjavajući krajolike i vedute dekorativnim genre-scenama. ${ }^{49} \mathrm{Na}$ slike djevojke na terasi pred kućom, pod brajdom ili na javnom zdencu, nadovezuju se umjetničine kasnije slike žena s djecom na rivi i na ulici. Njezine glavne teme nisu ni žuljeviti rad ni ženska samosvijest, jer motivi ribara i žena kraj obale naznačuju svakodnevni život, a djevojke na osami, pokraj zdenca, kakva zida ili stubišta, prikazane su u trenucima predaha ili meditacije. Leontine nije ni društveni kritičar ni borac za ženska prava nego ponajprije slikarica krajolika, zakutaka i ambijenata primorskih gradića. ${ }^{50}$ Varijacije djevojaka pod pergolom i na zdencu, žena na ulici i na rivi, podsjeća da su omiljene i po ukusu ondašnjih opatijskih turista, te da ona živi od svoga slikarstva i ovisi o konvencionalnom tržištu. Sjevernjacima su to bile amblematske slike juga što su ih najčešce identificirali s popularnim talijanskim ambijentima. $U$ vezi sa slikama koje se pripisuju zajedničkom radu, poput prizora iz opatijskog parka, postavlja se i pitanje jesu li ih Olga i Leontine doista slikale zajedno, oslikavajući svaka svoj dio platna, ili je možda jedna započinjala a druga nastavljala i dovršavala sliku. Isto je tako i pitanje je li motive pralja i djevojke pod pergolom, kao i novije slike, poput onih iz opatijskog parka koje su im također nalik, Leontine preuzela od Olge ili je bilo obratno. ${ }^{51}$

Teško je ustvrditi točno vrijeme promjene raspoloženja, kolorita i stila, no početkom devedesetih krajolici počinju biti svjetliji i življih boja. Kada početkom 1890-ih Leontine i Olga zajedno odlaze slikati na otvorenom, boje oživljavaju i navješćuju slobodniji pristup i kolorističku razigranost koja će se u potpunosti razviti tek nakon sredine devedesetih. ${ }^{52}$ Nakon niza nedatiranih slika kojima samo približno možemo odrediti vrijeme nastanka, bitna je slika, na neki način i prekretnica, Na opatijskom molu. Tri tjedna u Opatiji naslikana u veljači 1892. (sl. 6). ${ }^{53}$

$\mathrm{Na}$ ovoj slici, naslikanoj u ulju, more i nebo gotovo su akvarelno razliveni. Parobrod iznad kojeg se diže dim i putnici zakriveni šumom crnih kišobrana pretvoreni su u tamne siluete raspoređene duž lukobrana. U sivilu Leontinine slike naziru se jedva vidljive primjese slabog crvenila, u raslinju uz obalu, u dimu iznad broda i odrazu u vodi. Unatoč nedostatku boja, posve je očito da ova slika iskazuje nov ukus. Još je u jednom ona iznimka u Leontininu radu. 


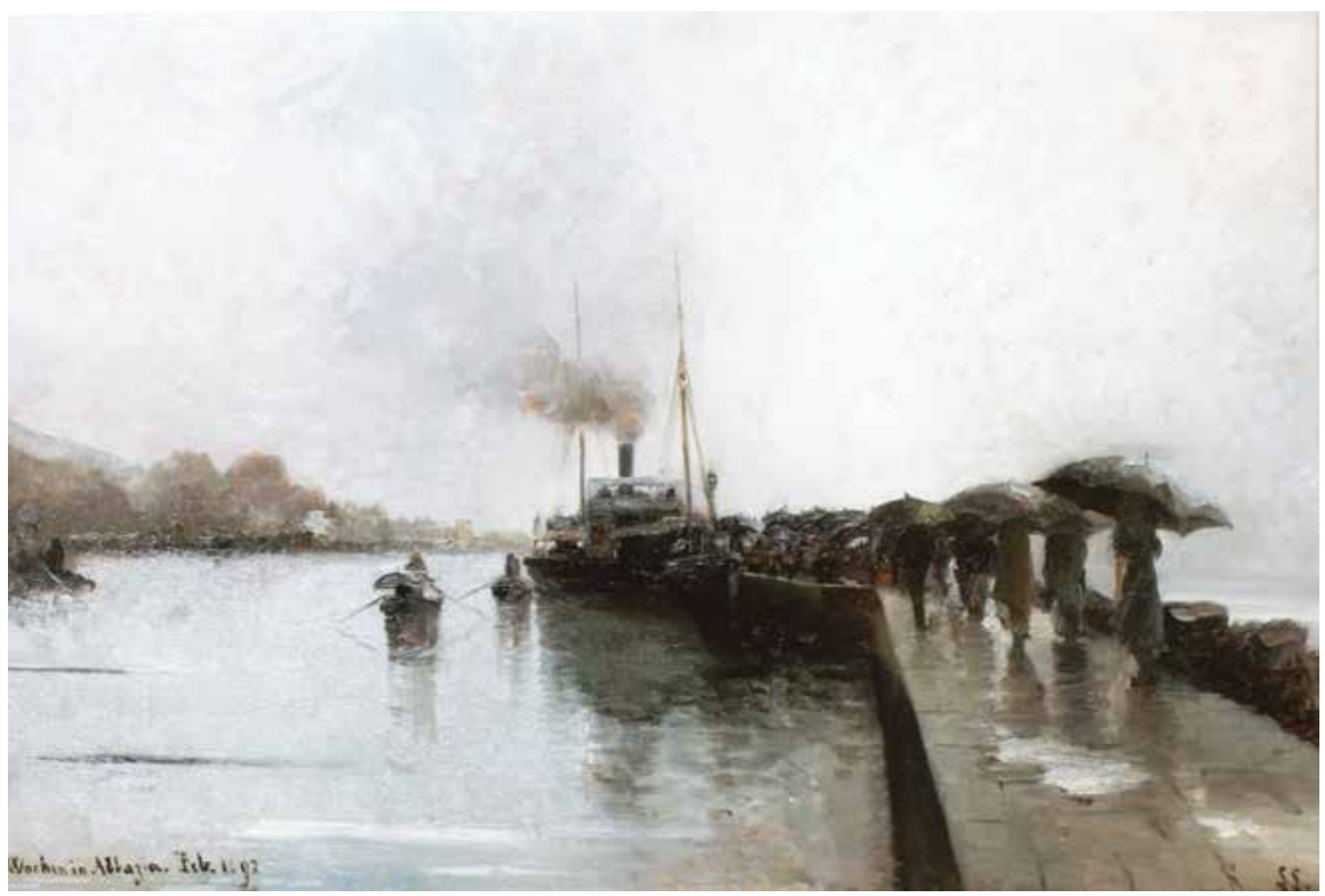

6. Leontine Littrow, Na opatijskom molu. Tri tjedna u Opatiji, veljača 1892., ulje na platnu, $36,8 \times 57,8 \mathrm{~cm}$, privatno vlasništvo, Beč / Leontine Littrow, On the pier in Opatija. Three weeks in Opatija, February 1892, oil on canvas, $36.8 \times 57.8 \mathrm{~cm}$, private collection, Vienna

Iako na slici nema ničega osim lukobrana i raslinja na obali, ona podsjeća na urbani život koji se vodi u blizini. Umjesto uobičajenoga pučkog ugođaja ribara i pralja, parobrod i putnici podsjećaju na moderno, građansko doba i tehnički napredak. Ovo je jedina slika Leontine von Littrow koja priziva suvremeni život. Pokoja opatijska palma i poneka naznaka balustrade na nekim slikama ne izgledaju gradski nego mondeno i ladanjski.

Među slikama koje izgledaju bitno drugačije od ostalih izdvajaju se i malobrojni interijeri, poput slika Moj atelijer u Opatiji i $U$ atelijeru. ${ }^{54} \mathrm{U}$ odnosu na većinu njezinih ulja naslikanih u eksterijeru, obje slike atelijera izgledaju gotovo kao da nisu njezine. U odnosu na ostale radove neuobičajen je i način slikanja i težak kolorit i prigušeni potezi. U Mojem atelijeru u Opatiji u posve zamračenu unutrašnjost impresionistički se probija snop sunčeve svjetlosti koja postaje gotovo materijalna i oštro se zasijeca u prostor. No težina i zasićenost posve odudara od drugih slika. Teški i šaroliki tepisi i debele, čupave tkanine ( $U$ atelijeru), drugačiji su zadatak od uobičajenoga, a novo iskustvo koje nije mogla steći u vanjskom prostoru, traži i bitno drugačiji pristup.

Unatoč pariškom učitelju, plenerizam i impresionizam u Opatiju stižu iz Beča, ishodišta »impresionizma ugođaja« (Stimmungsimpressionismus). Slikari koji češće dolaze u
Opatiju, poput Olge Wisinger-Florian i Marije Egner, do sredine devedesetih još uvijek slikaju u prigušenoj paleti te još nisu ni nadomak svijetlom i živom plenerističkom kolorizmu. Prijelom koji se u Beču događa s odvajanjem grupe umjetnika od konvencionalnoga umjetničkog udruženja, osnivanjem »Secesije« (1897.), novoga umjetničkog društva, svakako je obilježio i malu opatijsku skupinu umjetnika.

Leontine pleneristički postupak usvaja prije bečke secesije i prije niza samostalnih izložbi što ih održava u Continental Gallery u Londonu. Prije prve londonske izložbe otvorene u studenome 1896. počinje slikati slobodnim, pastoznim i skicoznim načinom. U svoje je slike već dotad unijela osobito svjetlo koje još uvijek zbunjuje i golica nenavikle oči publike i kritike. Tada već radi na otvorenom te, umjesto slika većih formata naslikanih $\mathrm{u}$ atelijeru prema skicama nastalim u prirodi, slika jednostavne male slike koje publici onog vremena izgledaju kao priprema za slikanje u atelijeru. Slike Leontine Littrow suvremenicima izgledaju tek kao studije i predlošci za "prave« slike. Njezin stil navodi na pomisao da slika brzo i lako. Način vođenja kista, nabacivanje slojeva boje kistom i lopaticom te brzo nanošenje poteza, pokazuje da je riječ o studijama naslikanim u svega nekoliko sati, a ne o slikama koje su plod višednevna rada u atelijeru (sl. 7). Slikanje pod otvorenim nebom potiče i uvođenje 


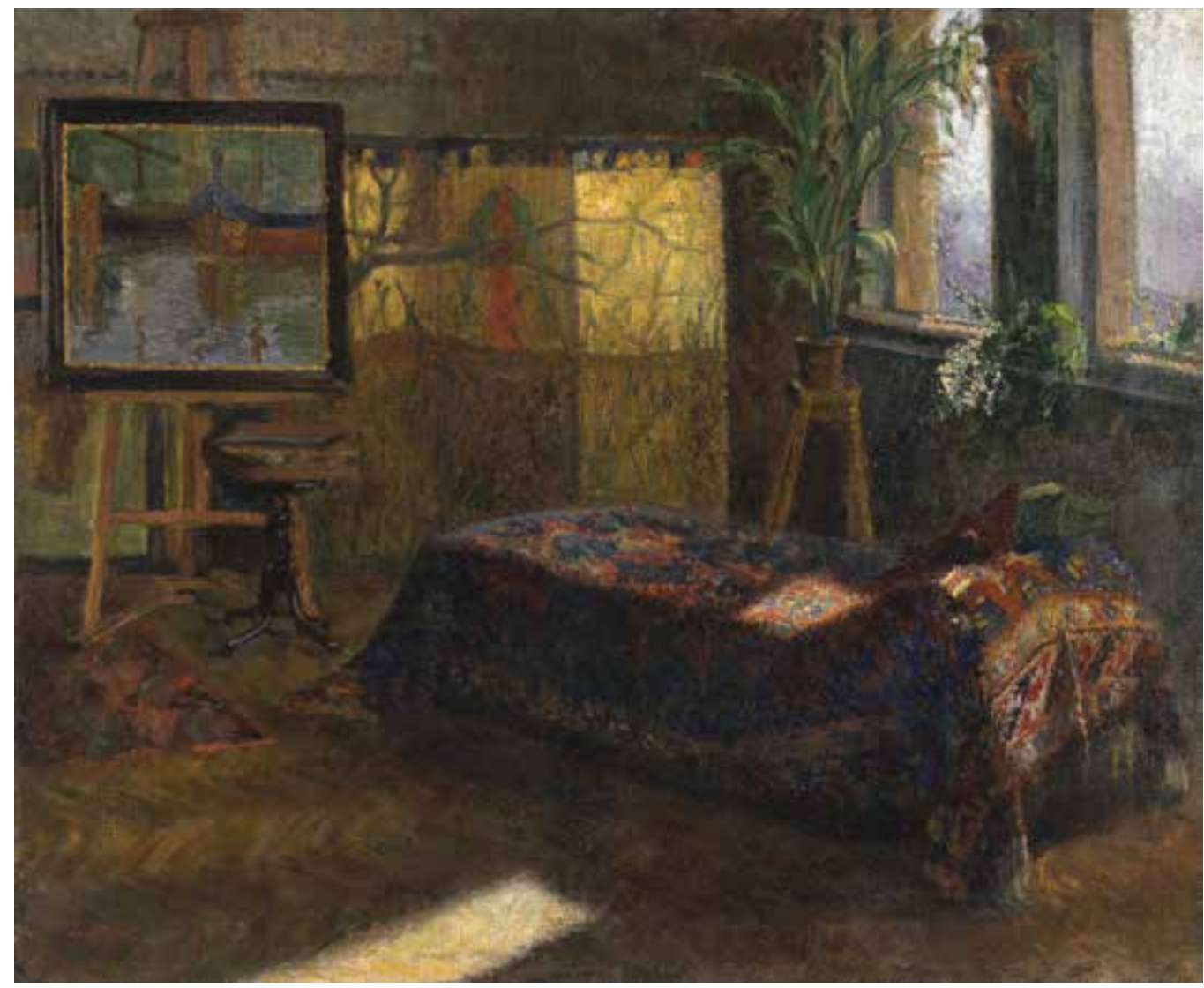

7. Leontine Littrow, Moj atelijer u Opatiji, 1890-ih, ulje na platnu, $64,5 \times 77,5 \mathrm{~cm}$, Wien Museum / Leontine Littrow, In my studio in Opatija, $1890 \mathrm{~s}$, oil on canvas, $64.5 \times 77.5 \mathrm{~cm}$, Wien Museum

različitog ugođaja, katkad jutarnjega, katkad podnevnoga, katkad večernjega. I kritika njezine radove gotovo isključivo doživljava kao skice. ${ }^{55}$

Slobodna interpretacija krajolika u Leontininim je slikama uočljivija nego u djelima nekih drugih slikara nastalim potkraj 19. stoljeća. Nakon ranih, romantičarski intoniranih radova osamdesetih, u zrelim plenerističkim i impresionističkim slikama pastoznih nanosa i prštavih boja, osim kista povremeno koristi i lopaticu. Slika uglavnom male formate koji su joj na putovanjima jedino mogući. Uz odlaske u Veneciju i druga obližnja mjesta i gradove (Duino kod Trsta i Belluno), nakon sredine devedesetih Leontine se sve češće upućuje i u slikarske pohode prema jugu. Da bi upijala ugođaje koje ne može naći u opatijskoj okolici, od 1897. odlazi na Krk i Lošinj, potom i Rab i Pag, a od 1900. odlazi u Dalmaciju, na Vis i Hvar, u Šibenik, Trogir i Split te Dubrovnik. Po nekim od naslova na izložbi Jadranski otoci ipogled na Austrijsku rivijeru koja je otvorena u studenome 1897. u Continental Gallery, vide se njezini motivi i kretanje: Ulica na Rabu, Djevojka na zdencu, Obala na Cresu, Zdenac u Opatiji, Pergola u Opatiji, Zdenac pod pergolom u Opatiji, Dvorište na Rabu, Pergola u mom vrtu, Ulica u Cresu, Među ruinama na Rabu, Stare zidine Krka, Riva u Dragi kod Opatije, Porta Pisana na Krku, Zdenac u Dragi, Luka u Krku, Stubište u vrtu Ville Angioline u Opatiji, rezidenciji njemačkog Cara, Obala u Dragi, Obala na otoku Krku, Kišno jutro u Dragi, Ribarsko mjesto u blizini Lovrana (Ika?), Ulica u Lovranu, Ribarske brodice u Opatiji, Skica iz Drage, Popodne u Dragi, Molo u Iki pokraj Opatije, Kuhinja u Opatiji, Ribarske mreže, Studija Krka, U Lovranu i Pranje u Dragi. ${ }^{56}$

Nakon očeve smrti 1895. nema više nikakvih obaveza koje bi je zadržavale kod kuće. Nakon prizora opatijskih i riječkih parkova i vrtova, borovi i čempresi, palme i agave u okolišu dalmatinskog juga doprinose posve drugačijim kompozicijama i drugim bojama, često i kombinacijama koje su više plod slikarskog raspoloženja nego odraza krajolika.

Početkom 20. stoljeća otoke sve više obilježava kriza i izolacija, potom i pojačano prekomorsko iseljavanje. Ti netaknuti krajolici postaju važni motivi, mjesta njezinih redovitih dolazaka. Od kraja osamdesetih sve više Bečana dolazi u Dalmaciju, a brojni poznati slikari krajem osamdesetih dolaze u Istru i Dalmaciju i rade ilustracije za znamenito enciklopedijsko izdanje Austro-Ugarska Monarhija u riječi i slici (Die österreichisch-ungarische Monarchie in Wort und Bild). Istri, Hrvatskom primorju i Dalmaciji posvećeni su 10. i 11. svezak, objavljeni 1891. i 1892.

Kada je potkraj devedesetih engleski kritičari pitaju o školovanju u Parizu i Münchenu, izbjegava konkretan od- 


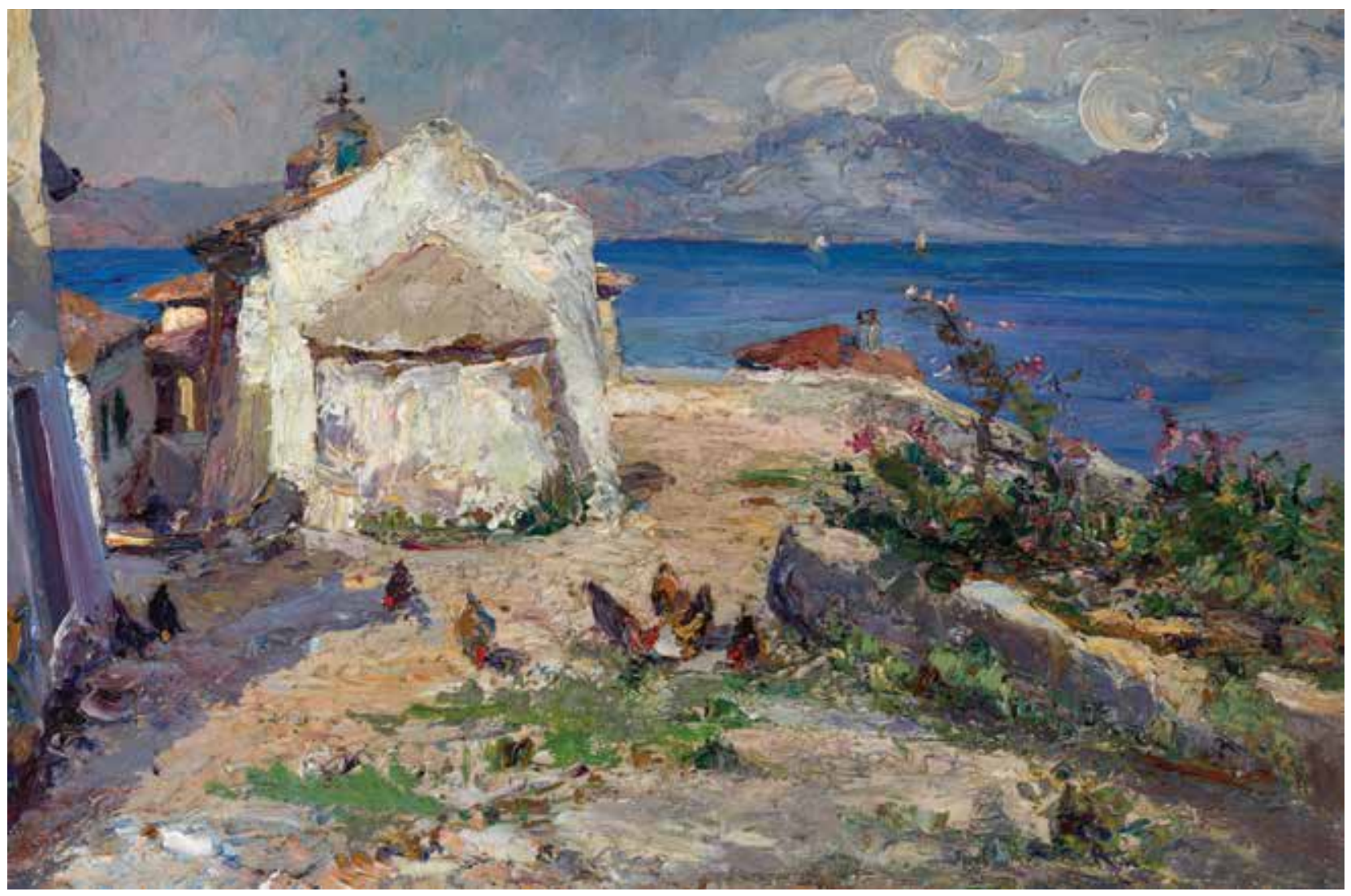

8. Leontine Littrow, Kokoši pokraj crkvice, oko 1900., ulje na platnu na kartonu, $33 \times 47 \mathrm{~cm}$, privatno vlasništvo, Beč / Leontine Littrow, Hens near the church, $c$. 1900, oil on canvas on cardboard, $33 \times 47 \mathrm{~cm}$, private collection, Vienna

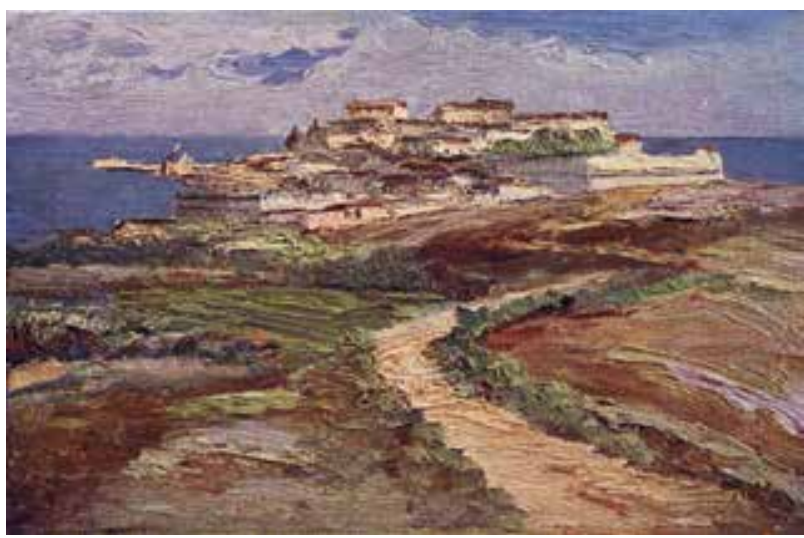

9. Leontine Littrow, Pogled na Cotrone, reprodukcija u boji u knjizi Georga Gissinga, By the Ionian Sea, Chapman and Hall, London 1901. / Leontine Littrow, View of Cotrone, colour reproduction in Georg Gissing, By the Ionian Sea, Chapman and Hall, London 1901

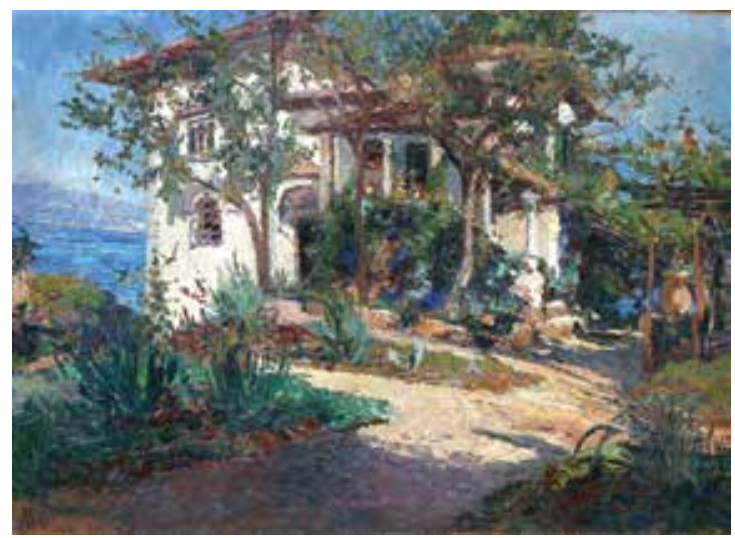

10. Leontine Littrow, Vila Magnolija, Lovran, 1900-ih, ulje na kartonu, $35 \times 48,5 \mathrm{~cm}$, privatno vlasništvo, Beč / Leontine Littrow, Villa Magnolia, Lovran, 1900s, oil on cardboard, $35 \times 48.5 \mathrm{~cm}$, private collection, Vienna govor, te izjavljuje da je "priroda njezina najbolja učiteljica" i da je »uvijek slikala natkrivena plavim nebom i okružena samo priprostim i slikovitim seljacima s otoka koje je toliko voljela«. ${ }^{57}$ Iako joj se katkad pripisuju i slike iz mondenih ljetovališta na Tirenskom moru, poput Negrija, Amalfija i Caprija, kao i slike egzotičnih sredozemnih krajeva - Tunisa i Maroka - riječ je o djelima koja joj se pogrešno pripisuju ili o pogrešnim opisima slika koje zapravo prikazuju jadranske motive, poput pogleda na grad Krk s katedralom i lukovicom zvonika koji mnogima izgleda orijentalno. ${ }^{58}$

Ilustracije što ih u siječnju 1901. radi za knjigu o Kalabriji, ne posjećujući talijanski jug nego na osnovi autorovih crteža, podsjećaju da uglavnom ne putuje mnogo dalje od Venecije, Beča i Dubrovnika. ${ }^{59}$ Zbog potrage za ilustratorom 


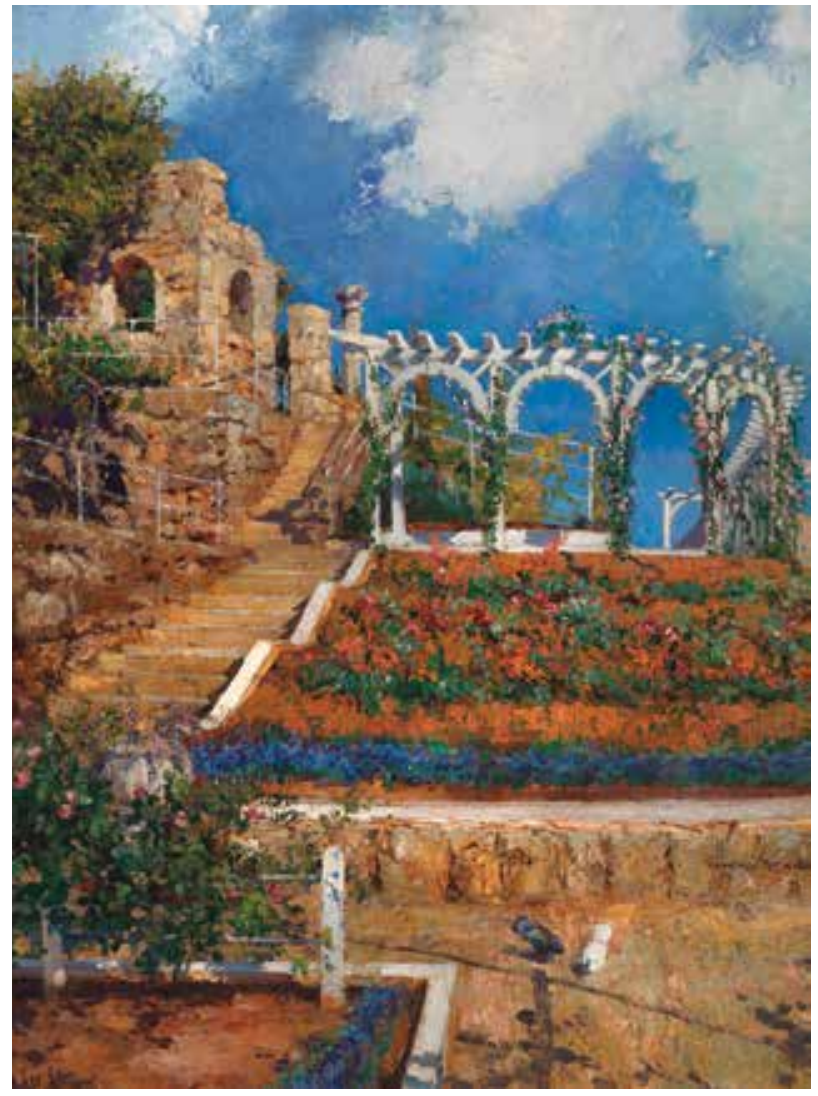

11. Leontine Littrow, Vidikovac, 1900-ih, ulje na dasci, 63,5 × 48 $\mathrm{cm}$, privatno vlasništvo, Beč / Leontine Littrow, Belvedere, 1900s, oil on panel, $63.5 \times 48 \mathrm{~cm}$, private collection, Vienna

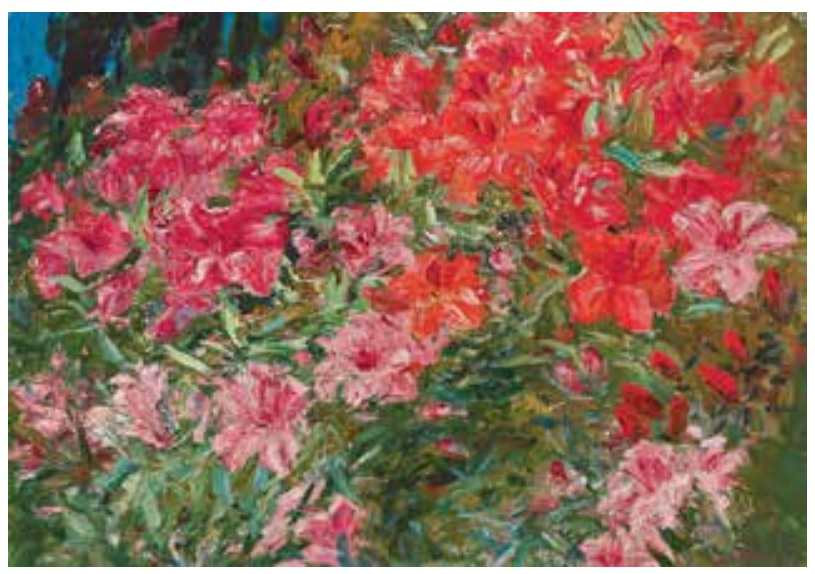

12. Leontine Littrow, Studija cvijeća iz vrta Ville Angioline u Opatiji, 1900-ih, ulje na platnu na kartonu, 32,5 $\times 46 \mathrm{~cm}$, privatno vlasništvo, Beč / Leontine Littrow, Study of flowers from Villa Angiolina in Opatija, 1900s, oil on canvas on cardboard, $32.5 \times 46$ $\mathrm{cm}$, private collection, Vienna

objavljivanje se knjige oteglo nekoliko mjeseci. Putopisac je za Leontinu saznao od izdavača, o čemu govori 3. siječnja 1901. u pismu svojem agentu te kaže da ga nakladnička kuća Chapmann and Hall obavješćuje da su »našli izvrsnog ilustratora knjiga«. Iako je tada bio "presretan«, kada su mu 17. veljače stigle »skice u ulju «, zapisao je u svoj dnevnik da mu se ne sviđaju, no vjeruje da će u knjizi izgledati zgodno. ${ }^{60}$

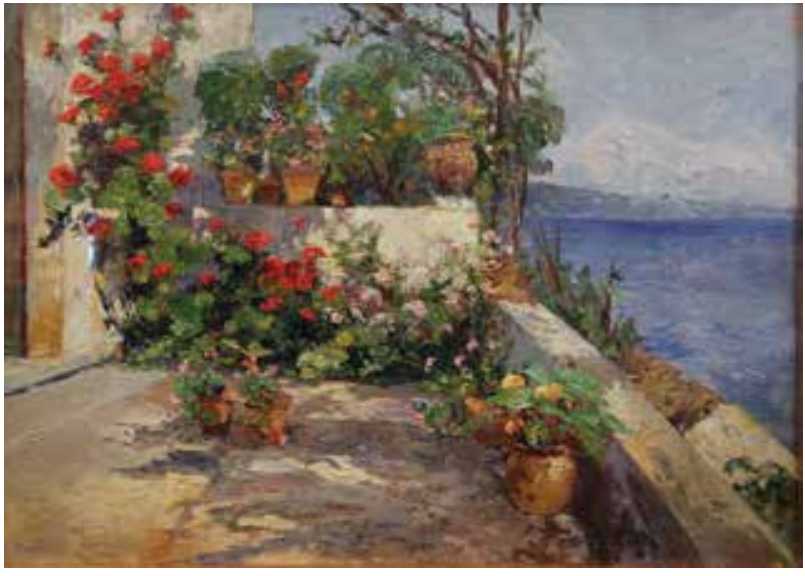

13. Leontine Littrow, Cvjetnjak na terasi pokraj mora, oko 1900ih, ulje na platnu, 52,2 ×71,6 cm, vl. Velimir Altabas, Rijeka / Leontine Littrow, Flower garden on a terrace near the sea, c. 1900s, oil on canvas, $52.2 \times 71.6 \mathrm{~cm}$, collection of Velimir Altabas, Rijeka

Piščeve skice nisu joj omogućavale da prizore zorno i vjerno naslika, a ni da ih je gledala uživo ne bi ih možda naslikala po njegovoj volji. Slike a ne ilustracije, izrađene su u podosta slobodnoj interpretaciji, pa autor nije bio oduševljen rezultatom. Od osam ilustracija u boji tri prikazuju motive iz Taranta, dvije pogled na Crotone, te po jedna Reggio Calabria, Promontorio Lacino i Squillace. Slike prikazuju vedute gradova (Taranto) i mnogo uže vizure (Most $u$ Tarantu, slika ribarskog čamca s vršama na pramcu), te daju uvid u razvoj njezina slikarstva na prijelomu stoljeća (sl. 9). Objavljene u dobrim reprodukcijama, slike pružaju uvid u Leontinino slikarstvo na smjeni stoljeća. Naslikane su pastozno, snažnim potezima, čvrsto i sigurno, doimlju se južnjačkim suncem, blještavim svijetlim i naročitim kolorizmom, kako je to o njezinim radovima pisala kritika. Unatoč putopiččevu nezadovoljstvu, Leontinine »impresionističke ilustracije u boji« primljene su s pohvalnim ocjenama. »De Littrow je također bila uvelike zadovoljna i odmah ga je pozvala da napiše knjigu o Dalmaciji. « ${ }^{61}$

Od knjige o Dalmaciji i od novih ilustracija L. Littrow nije bilo ništa. U svakom slučaju ona i dalje, sličnim načinom slika predjele opatijske okolice, kvarnerskih otoka i južnih, dalmatinskih krajeva. ${ }^{62}$

Na prijelazu stoljeća u njezinim uljima buknule su naročito žive kombinacije boja (sl. 10). O tome svjedoči niz osunčanih stjenovitih uzmorskih krajolika s mediteranskim biljem (sl. 11-12), borovima i agavama, vrtovi pokraj bijelih kućica s ponekom palmom, šterne sa sjenovitim brajdama, ukrasnim grmovima, velikim cvjetnim loncima i još slikovitijim, raznobojnim busenjem cvijeća. Nikad prije i nikad poslije nije bilo toliko sunca i prštavila boja, toliko kolorističke igre i kontrastnih kombinacija jarkog sunca i dubokih sjena (sl. 13-14).

Uoči Prvoga svjetskog rata počinje mijenjati pristup, potezi joj postaju sve snažniji i pastozniji, a oblici sve izraženiji 


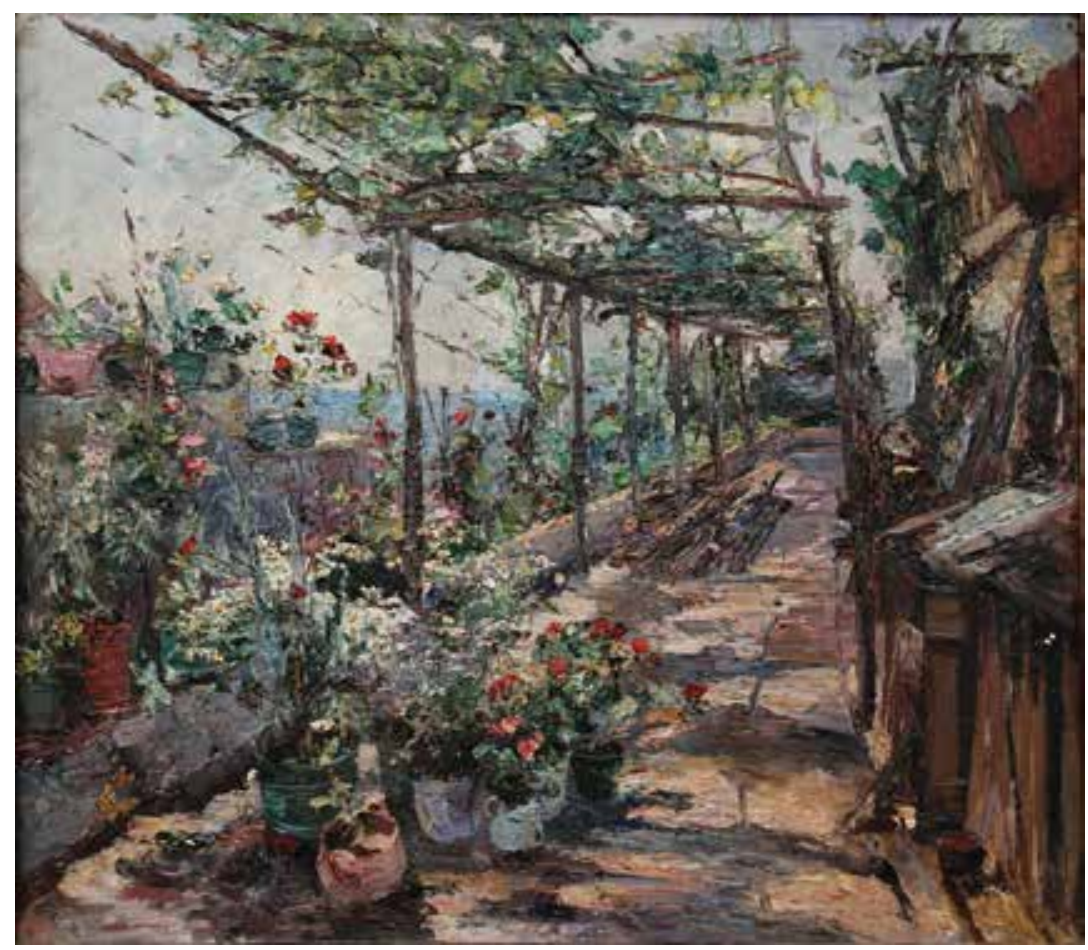

14. Leontine Littrow, Brajda, 1900-ih, ulje na platnu, $52 \times 59,5 \mathrm{~cm}$, vl. Željko Silić, Rijeka / Leontine Littrow, Grapevine, 1900s, oil on canvas, $52 \times 59.5 \mathrm{~cm}$, collection of Željko Silić, Rijeka

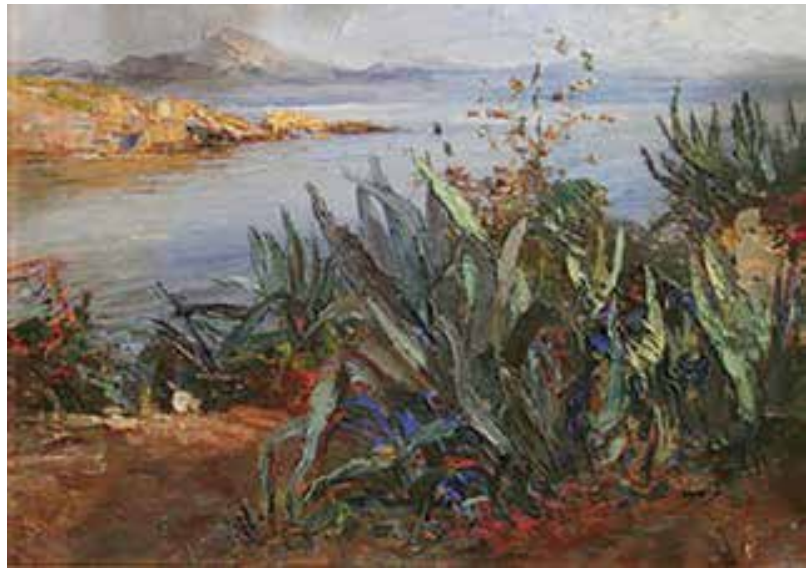

15. Leontine Littrow, Agave na Susku, 1908., ulje na kartonu, 34,5 $\times 47,5 \mathrm{~cm}$, bez signature, na poleđini gore lijevo upisano $»$ Leo Littrow, San Sego - Lussin, Jan 1908«., vl. Sandra Silić-Đipić, Rijeka / Leontine Littrow, Agaves on Susak, 1908, oil on cardboard, $34.5 \times 47.5 \mathrm{~cm}$, unsigned, inscription on the back above left "Leo Littrow, San Sego - Lussin, Jan 1908", collection of Sandra SilićĐipić, Rijeka

i zgusnutiji, upućujući na novi pristup (sl. 15-16). Motivi su sve jednostavniji i moćniji, zapjenjeni se valovi razbijaju o slikovite stijene, a slike se svode na guste površine mora, niske jednolične obale i svijetlo nebo. Te su joj kasne, sažete slike naglašenih struktura, ritma i snažne ekspresivnosti, poput Parka u Opatiji (sl. 17) te više slika Mora i stijena, posve potisnule prijašnje impresionističke trenutačne ugo-

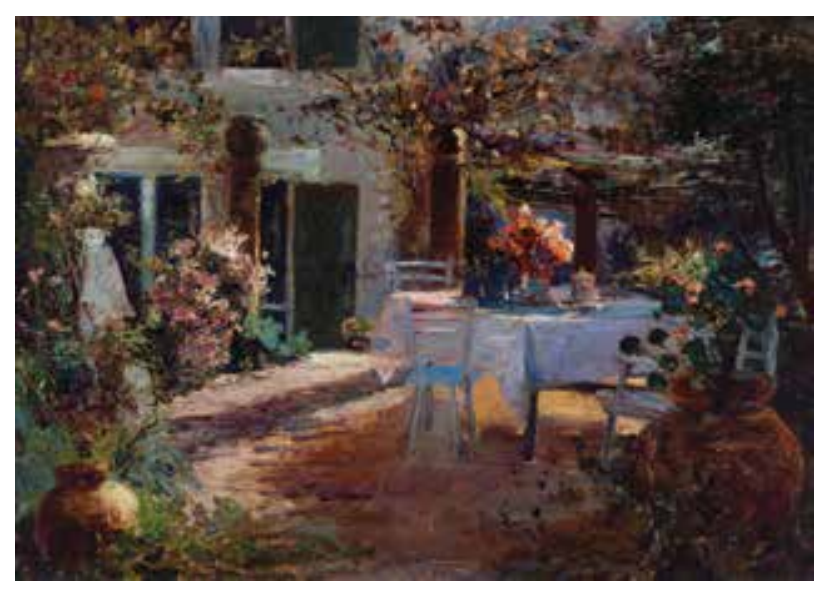

16. Leontine Littrow, Merenda nel Giardino / Doručak u vrtu, oko 1910., ulje na platnu i kartonu, $43,5 \times 62 \mathrm{~cm}$, privatno vlasništvo, Beč / Leontine Littrow, Merenda nel giardino / Breakfast in the garden, c. 1910, oil on canvas on cardboard, $43.5 \times 62 \mathrm{~cm}$, private collection, Vienna

đaje različitih svjetlosnih i atmosferskih promjena. Ni Večer u Velom Lošinju (sl. 18), izložena 1910. na izložbi bečkog udruženja slikarica, ne izgleda kao prolazna sumračna impresija koja će se uskoro ugasiti i nestati nego kao postojan prizor naglašenih oblika. Isto bi se moglo reći i za kasne slike iz opatijskih parkova; kada se kroz guste i neprovidne krošnje probije žuta svjetlost, jednako je materijalna kao 


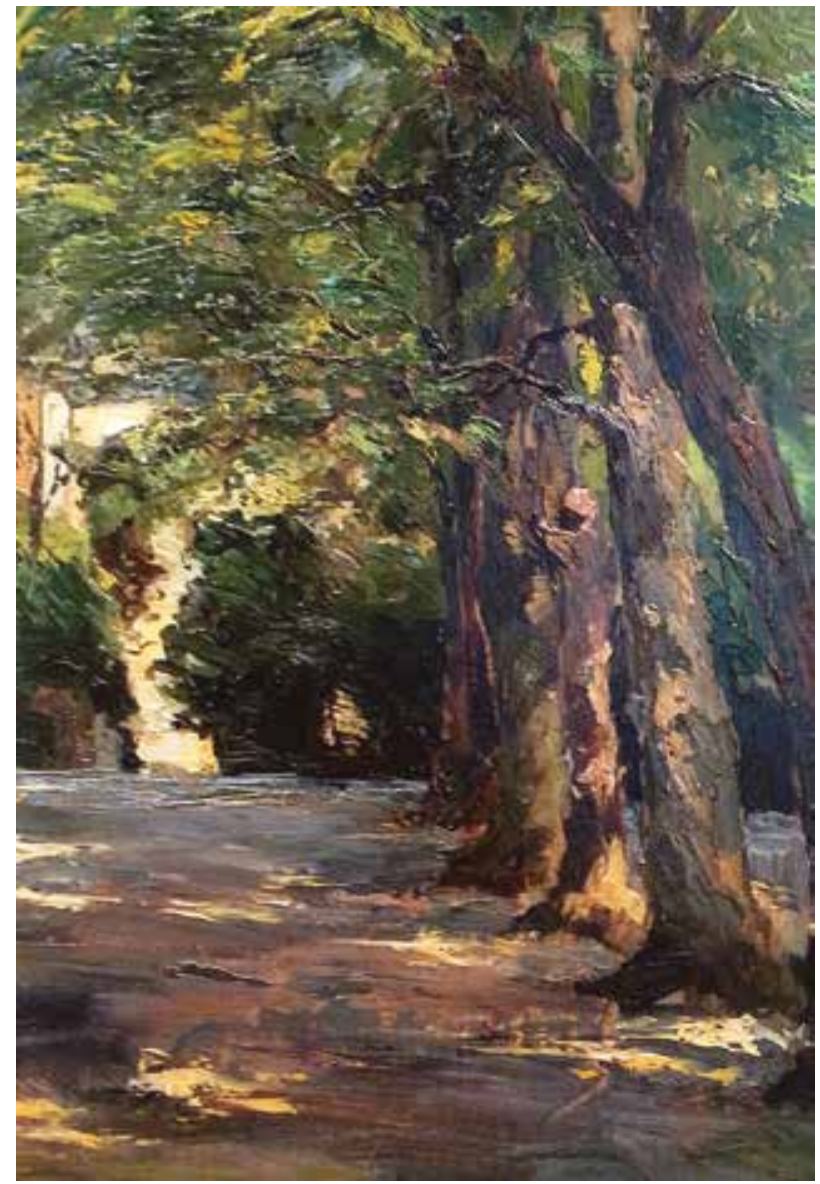

17. Leontine Littrow, Park u Opatiji, oko 1910., ulje na dasci, $34,7 \times 23,7 \mathrm{~cm}$, privatno vlasništvo, Beč / Leontine Littrow, Park in Opatija, c. 1910, oil on panel, $34.7 \times 23.7 \mathrm{~cm}$, private collection, Vienna

i bujno zelenilo, a uzajamni ritam zelenih i žutih ploha stvara naročite odnose koji više nemaju ništa zajedničko s prijašnjim svjetlosnim igrama u slikama pergola i sjenica, u kojima je koristila posve drugačiji učinak proboja raspršenih sunčevih zraka, te postizala naročitu prozračnost i odnose osunčanih i zasjenjenih dijelova.

Prijašnji pleneristički i impresionistički pristup, mediteranska svjetlost i šarolikost čistih boja počinje se mijenjati te se nameću jednostavni i postojani oblici. Posljednjih godina Leontine svodi svoje motive na osobito pastozne površine nabačene vidljivim potezima kista. Umjesto slaganja paralelnih nizova potezi često postaju uzvijoreni i kružni (sl. 19). U ponekoj se kasnijoj slici prožimaju simbolističko i ekspresionističko raspoloženje, kao u prizoru ljubičastocrvenog zalaska sunca i velikih čempresa u prvom planu.

Posljednjih ratnih i prvih međuratnih godina, ne mijenjajući motive i ne tražeći naglašeno novu vizualnost, Leontine Littrow slika radove koji ne upućuju na bliski kraj umjetničkog i životnog puta (sl. 20).
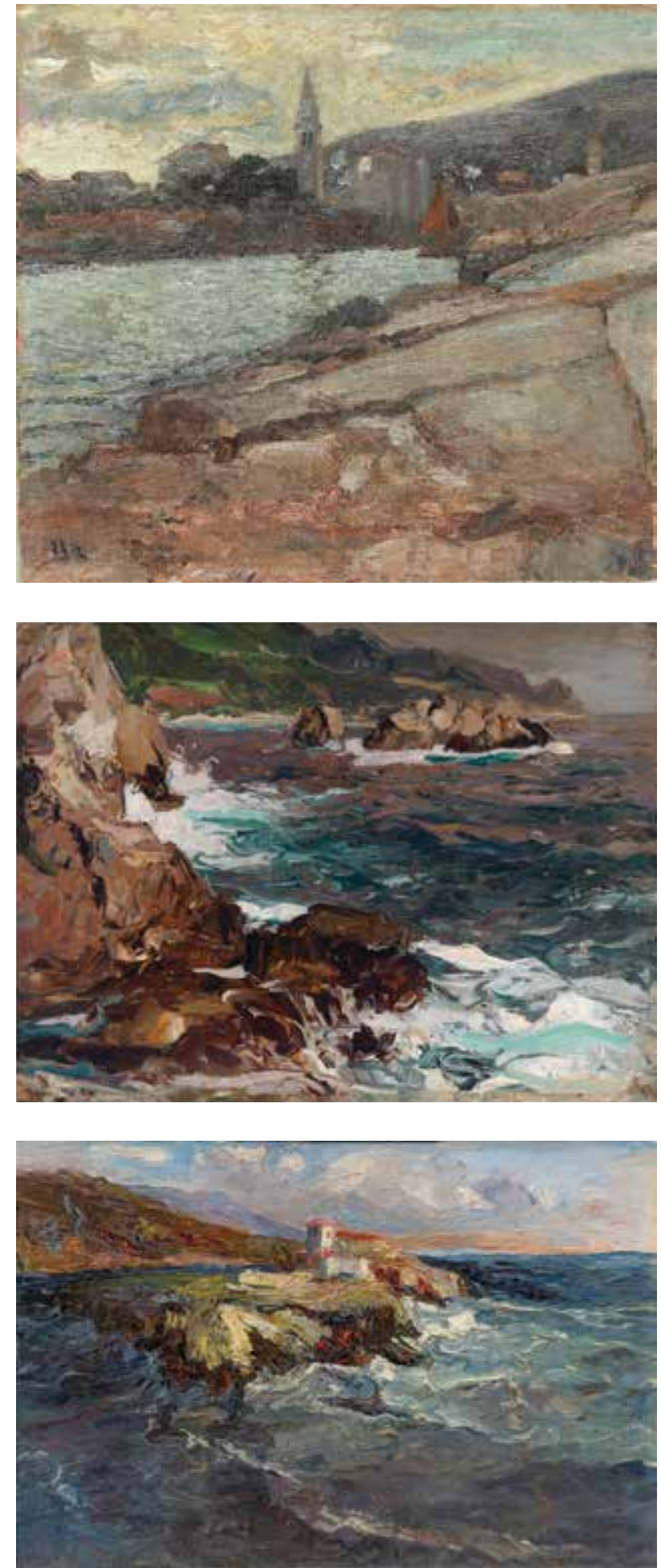

18. Leontine Littrow, Večer u Velom Lošinju, oko 1910., ulje na kartonu, $34 \times 37,5 \mathrm{~cm}$, privatno vlasništvo, Beč / Leontine Littrow, Evening in Veli Lošinj, c. 1910, oil on cardboard, $34 \times 37.5 \mathrm{~cm}$, private collection, Vienna

19. Leontine Littrow, Crkva na otočiću, 1919.-1920., ulje na platnu na kartonu, $32 \times 48 \mathrm{~cm}$, privatno vlasništvo, Beč / Leontine Littrow, Church on an island, 1910-1920, oil on canvas on cardboard, $32 \times 48 \mathrm{~cm}$, private collection, Vienna

20. Leontine Littrow, Stijene, 1919.-1920., ulje na kartonu, $31 \times 41$ $\mathrm{cm}$, privatno vlasništvo, Beč / Leontine Littrow, Cliffs, 1910-1920, oil on cardboard, $31 \times 41 \mathrm{~cm}$, private collection, Vienna 


\section{Izložbe i odjeci}

Na velikim godišnjim i međunarodnim izložbama u srednjoeuropskim zemljama i Njemačkoj Leontine sudjeluje već od početka osamdesetih. ${ }^{63} \mathrm{Od} 1882$. redovito izlaže u Beču na izložbama Künstlerhausa (1882.-1887., 1892.-1894., 1896.), u Salonu Pisko (1899., 1901. i 1904., 1906.), kao gošća grupe Osam umjetnica (Acht Künstlerinnen), te 1910. u paviljonu Secesije na izložbi Austrijskog udruženja likovnih umjetnika "Secesija«, u sklopu Austrijskog udruženja likovnih umjetnica (1910.). ${ }^{64}$ Izlaže i u Budimpešti (1884.), Salzburgu (1885., 1891., 1896.), Londonu (1886.), Brnu (1888.), Pragu (1891.), Wrocławu (1892.), Münchenu (1893., 1903.), Černivcima (1906.), Klagenfurtu (1907.) i Kopru (1910.). ${ }^{65}$

Leontine Littrow izlaže i na Svjetskoj kolumbijskoj izložbi u Chicagu (1893.) na kojoj je tada poseban prostor Women's Pavillion - bio namijenjen slikaricama; izlagale su i austrijske slikarice. ${ }^{66}$ Izlaže i na velikoj gospodarskoj Austrijskoj izložbi u Londonu 1906. na kojoj su, osim bečkih udruženja poput Künstlerhausa, Hagenbunda, Secession i Acht Künstlerinnen, predstavljena brojna austrijska regionalna i nacionalna umjetnička udruženja, poput slovenske "Save« iz Ljubljane i drugih. ${ }^{67}$ Iako Opatija pripada Austrijskom primorju - Markgrofoviji Istri, ona izlaže s dalmatinskim umjetnicima. Nastupa zajedno s Vlahom Bukovcem, Emanuelom Vidovićem, Ivanom Meštrovićem, Antoniettom Bogdanović-Cettineo, Markom Rašicom i izlaže Vis, Otok Rab, Dubrovnik, Šibenik te Lošinj i Velebit.

Posebnu pozornost privlače njezine izložbe u Londo$\mathrm{nu}, \mathrm{u}$ kojem od srednjoeuropskih umjetnika obično izlažu umjetnici okupljeni oko izložbi Glaspalasta u Münchenu, kao što su od Francuza najčešće zastupljeni slikari pariškog Salona. Na prvom nastupu u Londonu, na godišnjoj izložbi Kraljevske akademije (Royal Academy) 1886., kritičar primjećuje »suzdržanu snagu u prigušenom koloritu Tihog zakutka Venecije«, jedine njezine izložene slike. ${ }^{68}$ Najviše joj uspjeha donosi niz samostalnih izložbi u Continental Gallery u Londonu, u kojoj redovito izlaže od 1896. do 1899. godine. Ta galerija u znamenitoj ulici trgovaca umjetninama, New Bond Street, nalik bečkoj Dorotheergasse, tijekom dvadesetak godina posvećuje se upoznavanju Britanaca s kontinentalnom umjetnošću. Slike Leontine von Littrow privlače pozornost egzotičnim mediteranskim krajolicima.

Englezima je krajem 19. stoljeća Jadran potpuna nepoznanica te se u napisima o njezinim izložbama provlači i nepoznavanje njezine zemlje. Kritičari uglavnom ne znaju da se iza imena Leo de Littrow krije slikarica. K tomu često Austriju brkaju s Australijom, pa pišu o izložbi o "australskim rijekama«. Austrian Riviera postaje Australian Rivers! »Zakutci i kutovi Austrijske rivijere« postavljeni su u studenome 1896. Katalog izložbe kaže, među ostalim, da »izvanredna svježina svjetla i boje dokazuje da je Leo de Littrow otvorila novo područje za iskazivanje svoga um- jetničkog dara « ${ }^{69}$ Pedesetak »zakutaka i kutova « L. Littrow postavljeno je u posebnoj dvorani, dok su u ostale dvije prikazani izabrani radovi s pariškog Salona i slike norveških fjordova. ${ }^{70}$ Kritika odmah uočava svježinu i naročitu svjetlost L. Littrow koja posljednjih godina 19. stoljeća zrači iz njezinih radova: »M. Leo de Littrow izlaže zbirku malih slika i skica u ulju naslikanu u blizini Opatije na Jadranu. Boje su svijetle, možda malo previše, kompozicija djelotvorna i osobita, dok su platna općenito puna slikovitih pojedinosti. Naslikana su jakim, ponekad nedotjeranim sjajem sunčeve svjetlosti.«11 Lloydov tjednik zaključuje da se posjeta njezinoj izložbi »isplati« jer je »mnogim mjestima slikarica dala izvanrednu svježinu svjetla i boje«. ${ }^{72}$ Dnevne novosti Južnog Walesa kažu da je »De Littrow ponešto neujednačena i teška slikarica. Ali ona zna kako naslikati čistu svjetlost i olujni kontrast u tim sunčanim krajevima i kako upotrijebiti boje u komponiranju slike, a neki primjeri svijetle atmosfere daju osobit šarm njezinu radu. « ${ }^{73}$ Uz drugu njezinu izložbu jedan nedjeljni list primjećuje da je slaba strana njezinih slika »u istovjetnosti postupka, zbog kojega mnoge od njih izgledaju kao niz replika«. ${ }^{74}$

Glasgowski glasnik uočava da je Leontine Littrow prošle godine pokazivala slike isključivo naslikane u okolici Opatije, a da se "ovo ljeto uputila dalje i poslala slike otoka Raba i Krka, malo poznatih engleskim turistima, ali očito punim slikovitih mjesta «. ${ }^{75}$ Neki su kritičari donekle suzdržani u ocjeni njezina rada, smatrajući njezine male slike tek nedovršenim uljenim skicama, koje su uzajamno previše nalik jedne drugima. ${ }^{76}$ Uspjeh je ipak nedvojben, a kao osobito priznanje može se istaknuti i posjet princa od Walesa, prijestolonasljednika i budućega engleskog kralja, koji je izložbu razgledao 6. veljače 1898 . kada je posjetio i neke druge izložbe. ${ }^{77}$

Odjeci londonskih izložbi u Rijeci i u Beču bili su također naročito povoljni. Njezin uspjeh doživljen je kao promocija Primorja i Austrije. Riječka La bilancia ponosno govori o uspjehu prve londonske izložbe: »Ističemo s naročitim zadovoljstvom da zbirka od pedeset slika i studija gospođice Leo de Littrow [...] privlači iznimno brojnu biranu publiku velike metropole i predmet je najlaskavijih umjetničkih rasprava ${ }^{78}$

I kasnije izložbe imaju odjeke u domovini, o čemu svjedoči članak bečkog dopisnika iz Londona koji također ne zna da nije riječ o slikaru nego o slikarici. »Među radovima i zbirkama umjetnika iz stranih zemalja [...] radovi dobro poznatog i omiljena austrijskog slikara Lea v. Littrowa ove su sezone oduševili britanske poznavatelje umjetnosti. Nije pretjerano reći da je ovaj duhoviti umjetnik svojim trećim pojavljivanjem $u$ prijestolnici na Temzi ne samo dostigao prvo mjesto po prihvaćenosti kod britanske publike nego je štoviše prodro u široke krugove preko britanskog Kanala, otvarajući nov i jedinstven pogled u gotovo nepoznat sjaj austrijskog krajolika". 
Ističe i da je »svojim genijalnim koloritom i naročitim načinom gledanja u Continental Gallery izložio pedesetak slika, naslikanih u bližoj i daljnjoj okolici Opatije. Prikazujući otoke Lošinj, Rab i Krk postigao je velik učinak kod inače hladne anglo-saksonske publike. Ako započne trka engleskih turista - privučenih paletom mnogih čarobnih područja - u lovorove šumice i maslinike Jadranske rivijere, moramo to shvatiti kao nov trijumf austrijske umjetnosti. "9 $^{79}$

Posljednju je samostalnu izložbu u Londonu imala 1904. u kući slavnoga klasicističkog slikara i dugogodišnjeg predsjednika Kraljevske akademije lorda Frederica Leightona (1830.-1896.). Ta je neobična građevina u Holland Parku u Kensingtonu, izgrađena u orijentalnom stilu, za umjetnikovo stanovanje i rad, poslije bila namijenjena izložbama te je nakraju postala muzej slavnoga viktorijanskog slikara. Leontine izlaže ovdje među prvima, a svojom izložbom privlači osobitu pozornost, naročito »sjajnom paletom boja i prekrasnim krajolikom", kao i »majstorstvom i velikom brzinom slikanja«. Kritičar jednako hvali njezine slike kao i prirodne ljepote i kulturu dalmatinskih gradova. ${ }^{80}$

Nakon londonskih uspjeha, Leontine i u najužem zavičaju priređuje više izložbi. Iako poslije prve samostalne izložbe u Villi Angiolini u Opatiji 1893., priređenoj u dobrotvorne svrhe, nikad više ne izlaže samostalno ni u Opatiji ni u Rijeci, na izložbama opatijske Umjetničke kolonije (Künstler-Colonie »Abbazia«) priređenima 1900., 1901. i 1902. redovito izlaže brojne radove koji privlače pozornost kritičara: ${ }^{81} » \ldots$ i ona je privučena novom umjetnošću koju se naziva 'secesija' i koja obuhvaća različite vrste pristupa i različite manire. Pomalo je hrabar pristup kojim je naslikala, na primjer, Svjetla u rapskoj luci u kojima je jedinstvenom bojom, kao i naglašenom bjelinom - onom posebnom bjelinom planinskih stijena, postigala poseban izgled, koji je u živom kontrastu s ambijentom i ozračjem « ${ }^{82} \mathrm{U}$ Opatiji izlaže i na izložbi priređenoj uz Četvrti međunarodni kongres talasoterapije 1908. i na izložbi u Casino des Etrangers 1912. ${ }^{83}$

Zaokruženje njezina sudjelovanja u umjetničkom životu prijestolnice zapažena je samostalna izložba u Beču u Galerie Miethke 1914., priređena uoči samog rata. Naročito je zapažena neobična reljefnost njezinih pastoznih slika. ${ }^{84}$

Posljednjih godina sve manje putuje i sve je više vezana uz motive opatijske i riječke okolice koje izlaže i na svojim posljednjim izložbama u Rijeci, u vili nadvojvode Josipa (Villa Giuseppe, današnja zgrada Državnog arhiva) 1916., 1917., te 1918. na izložbi u Muškoj osnovnoj školi u Dolcu, kao i na prvoj poslijeratnoj izložbi u Circolo artistico $1924 .{ }^{85}$

Riječki su kritičari njezine nastupe ocjenjivali vrlo povoljno: "Littrow nas i ovoga puta zadivljuje lijepom kompozicijom i motivima, a zadivljuju nas također i njezine vedute. ${ }^{86}$

Sljedeće je godine hvali i izvjestitelj koji se unatoč humanitarnoj namijeni izložbe za pomoć siromašnim učenicima, ne ustručava priređivačima uputiti više prigovora, među ostalim i da amateri nisu bili odijeljeni od "pravih « umjetnika. Strogi se novinar nije libio verbalnih vratolomija i poetskih izljeva, a naglasio je da slikarica istražuje zadivljujuće učinke svjetla, kao i da njezine slike podsjećaju na kolorizam marina hrvatskog slikara Crnčića. A organizatorima je pak prigovorio da su joj slike na izložbi previše zbijene, pa ne dolazi do punog izražaja moderna tehnika kojoj su glavne osobine upravo punoća svjetla i žive boje. ${ }^{87}$

Niz izložbi započetih davnih osamdesetih i naročito uspješnih u Londonu potkraj 19. stoljeća i Beču početkom 20. stoljeća, zaokružuje u Opatiji i Rijeci.

U odnosu na znatne mijene ukusa u posljednjih stotinjak godina njezino se djelo pokazuje neobično postojano i izdržljivo te još uvijek iznimno svježei suvremeno. Iako Leontine Littrow nema osobitih doticaja s hrvatskim umjetnicima svoga doba, niti izravno pripada hrvatskoj umjetnosti kraja 19. i početka 20. stoljeća, treba je ipak ubrajati u »naše«.

Umjesto uključenosti u hrvatske umjetničke krugove, našom je čini osobita sklonost primorskim i dalmatinskim krajolicima, suosjećanje s hrvatskim pukom jadranskih otoka na kojima crpi svoje motive, kao i zanimanje za dalmatinsku narodnu kreativnost i rukotvorstvo. Iako su joj doticaji s hrvatskim umjetnicima uglavnom usputni i prigodni, ne treba ipak zanemariti činjenicu da se u Opatiji od 1900. do 1902. susreće i više puta izlaže zajedno s desetak godina mlađim Mencijem Clementom Crnčićem, s kojim je povezuje sličan način slikanja, kao i da na velikoj Austrijskoj izložbi u Londonu 1906. izlaže zajedno s dalmatinskim, a ne $s$ bečkim umjetnicima s kojima je dotad čvrsto povezana.

Njezina je važnost naročita i u kontekstu »ženskog slikarstva" koje se sve više širi otkad je u Beču osnovano Društvo spisateljica i umjetnica. Kao primorska, riječka i opatijska slikarica, naročito je zanimljiva u jadranskom kontekstu, u kojem se pojavljuje fenomen malo poznatih zadarskih umjetnica iz plemićkih obitelji Borelli i Bogdanović (Bogdanovich). ${ }^{88}$

Donedavno u Hrvatskoj posve zaboravljen i zapostavljen, opus Leontine Littrow napokon je na putu valorizacije. Njezine plenerističke i impresionističke kao i slike koje već pripadaju ekspresivnim tendencijama, naslikane uoči Prvoga svjetskog rata, svakako će izboriti svoje mjesto u slikarstvu na tlu Hrvatske.

\section{BILJEŠKE}

1 Nakon višegodišnjeg bavljenja slikarskom enigmom zvanom Leo Leontine Littrow, autor je temeljitija istraživanja započeo početkom rujna 2015. u dogovoru s Alfredom Kolhammerom, suvlasnikom Galerije Kolhammer \& Mahringer iz Beča, zahvaljujući povezivanju zajedničkog prijatelja, kolekcionara Milana Krivde. Zajedničkom projektu Muzeja grada Rijeke i Galerije Kolhammer \& Mahringer u organiziranju izložbe i objavljivanju monografije Leontine Littrow na hrvatskom i njemačkom jeziku, pridružio se i bečki povjesničar umjetnosti i pisac Bernhard Barta, a predviđeno vrijeme realizacije jest rujan 2017. godine. Zahvaljujem i Malcolmu Scotu Hardyju koji mi je pomagao pri istraživanju u Londonu. 
2 MARTIN SUPPAN, RUPERT FEUCHTMÜLLER, Marie Egner: Eine österreichische Stimmungsimpressionistin, Bd. II, Edition Martin Suppan, Wien, 1993. Im Kinsky je objavio monografije o Theodoru von Hörmannu, Rudolfu Altu i Robertu Russu. Galerija Belvedere je, uz izložbe, objavila monografije o Emilu Jakobu Schindleru (2012.) i Carlu Mollu (1998.). Najavljena je i monografija o Olgi Wisinger-Florian (Kunsthandel Giese \& Schweiger)

3 IVAN PEDERIN, Heinrich von Littrow kao pjesnik pomoraca i njemačke manjine u Hrvatskoj, Adrias, 1 (1987.), 287-321. IRVIN LUKEŽIĆ, Heinrich von Littrow, Fluminensia: časopis za filološka istraživanja, 6/12 (1994.), 1-14; GIANNI STELLI, Fiume e dintorni nel 1884: Heinrich von Littrow e la prima guida illustrata della Terra di S. Vito, Edizioni Italo Svevo, Trieste, 1995.

Leontinin djed, Joseph Johann von Littrow, rođen u Češkoj u protestantskoj obitelji, završio je studij prava i teologije na praškom Sveučilištu, no umjesto da postane odvjetnik posvećuje se astronomiji. Nakon predavanja na Sveučilištu u Krakovu i rada u opservatoriju Sveučilišta u Kazanu u Rusiji, dolazi u Beč i do kraja života vodi zvjezdarnicu.

4 Važni članovi obitelji Littrow: Joseph Johann von Littrow (1871. - Beč, 1840.), njegov sin Karl Ludwig (Kazan, 1811. - Venecija, 1877.), Karlova žena Augusta (1819.-1890.), njihova kći slikarica Ella, udana Lang (1841.-1912.).

5 ISO KRŠNJAVI, Zapisci: iza kulisa hrvatske politike, knj. I, Mladost, Zagreb, 1986., 384; ISO KRŠNJAVI, Zapisci: iza kulisa hrvatske politike, knj. II, Mladost, Zagreb, 1986., 709-710.

6 Leontinin otac jest mlađi sin upravitelja bečke zvjezdarnice i astronomov brat. Mornaričku akademiju završava dok je još bila u Veneciji. Sudjeluje i u ratnim događajima revolucionarne 1848., u austrijskoj pomorskoj blokadi Venecije, kao i u austrijsko-talijanskom ratu 1859. godine. Već 1857. Heinrich postaje profesor i ravnatelj Nautičke akademije u Trstu.

7 GIANNI STELLI (bilj. 3), 59-61. Heinrich von Littrow osim pomorskih priručnika piše pjesme i komedije, među kojima je najpoznatija Ksantipa (Xantippe, Wien 1880.), o ljubavlju zaslijepljenom mladom časniku koji za ženidbu treba dopuštenje svojega nadređenoga. Iako njegov zapovjednik isprva oteže s dopuštenjem, bojeći se da će mu ženidba umanjiti strast za mornaricom, kada upozna djevojku izdaje mu dopuštenje bez premišljanja, procjenjujući da će ga brak ubrzo nagnati da izbiva iz kuće i prione svom zvanju. Komedija je bila vrlo omiljena te je prevedena i na talijanski, hrvatski, engleski i ruski jezik i više puta izvođena. Na hrvatski je prevodi riječki župnik Ivan Fiamin, a izvode je u riječkoj Narodnoj čitaonici.

8 ISO KRŠNJAVI (bilj. 5, 1986., knj. II), 709-710.

9 IRVIN LUKEŽIĆ (bilj. 3), 5-6.

10 MyHeritage Stammbäume, URL: https:/www.myheritage.at/research/ collection-1/myheritage- (26. 2. 2016.); -, K. u. k. Marineoffiziere aus Velden, Veldner Zeitung, 15. prosinca 1986., 37. Zahvaljujem Ivanu Jeličiću koji je o obitelji Barry dobio poneki podatak u Trstu, prije svega fotografiju nadgrobne ploče obitelji Barry sahranjene na anglikanskom groblju.

11 Charlesov stariji sin, kapetan Richard Barry, zapovijedao je fregatom Novarra i 1864. odvezao u Meksiko nadvojvodu Maximiliana, bivšeg zapovjednika Ratne mornarice proglašenoga meksičkog cara. Njegov je brat, Alfred Ritter von Barry (1830.-1907.), sudjelovao 1866. u bitci kod Visa, a poslije je dosegnuo i visoki čin viceadmirala. Isti je čin stekao i Richardov sin, Wilhelm Richard Ritter von Barry (1861.-1937.), koji je 1892. sudjelovao u jednoj od austrougarskih polarnih ekspedicija, a bio je poslije i zapovjednik Mornaričke akademije u Rijeci. I u sljedećem je naraštaju bilo više mornaričkih časnika od kojih se jedan istaknuo u riječnoj mornarici na Dunavu, a drugi je zapovijedao podmornicom u Prvom i Drugom svjetskom ratu.

12 GIANNI STELLI (bilj. 3), 29. Heinrichovu ženu, majku njegove djece, neki zovu Ilka, a drugi Caroline Fanny i navode da je rođena 1832., a umrla 1862. godine. Usp. IRVIN LUKEŽIĆ, Robert Whitehead: engleski tvorničar torpeda iz Rijeke, Izdavački centar Rijeka, Rijeka, 2010. 123-124; MyHeritage Stammbäume, URL: https://www.myheritage.at/ research/collection-1/myheritage (26. 2. 2016.). Zbrka oko imena Hein- richove žene nastaje dijelom zato jer joj se i majka (London, 1804. - Pula, 1873.) i jedna od kćeri također zovu Matilde. No vjerojatno je ipak točan navod u Atti di morte, Parte 1, sastavljen u Voloskom-Opatiji 11. svibnja 1925., u kojem je uz podatke o Leontininoj smrti zapisano da je majčino ime Matilde. Isti se podatak ponavlja i u drugim dokumentima, onima o smrti obiju sestara, Elene i Leontine, pohranjenim u Državnom arhivu u Rijeci. U vezi s brojem Heinrichove djece podaci su neujednačeni i zbunjujući. Osobni dosje u Kriegsarchiv/Marine/Marine Qualifikation Liste, No 3127, svjedoči da je 1853. oženjen i da ima sina i kćer. U kasnijem izvještaju K. u. $k$ General Commando zu Agram za 1866. stoji da je udovac sa sinom i kćeri, no u izvještaju za 1867. piše da je udovac (od 1861.), ali da ima četiri nezbrinute kćeri! Iako je sin već umro, ispada da ima više djece nego ih je imao za ženina života! Na podacima iz Kriegsarchiva zahvaljujem dr. Ani Alebić Juretić.

13 Nije pronađena matična knjiga s upisom Leontinina rođenja. Općenito je prihvaćeno da je rođena u Trstu. Zna se i datum, no zbrka nastaje oko godine rođenja. Tomu je vjerojatno i sama pridonijela jer ugledni umjetnički leksikoni, objavljeni još za njezina života, navode godinu 1860., kao i najnovija izdanja leksikona, usp.: E. BÉNÉZIT, »Littrow, Leo von «, Dictionary of Artists, Vol. 9, Oxford, 2006., 1127: »Littrow, Leo von, Austrian, 19th century, Born 1860 in Trieste. Painter. Seascapes. Leo von Littrow worked in Munich, Vienna, Venice, Fiume, and Abbazia. He participated in exhibitions in Austria and Germany from 1880 onwards.«; K. G. SAUR, »Littrow, Leo von «, Allgemeines Künstlerlexikon: Bio-bibliographischer Index A-Z, Bd. 6, K. G. Saur, München-Leipzig, 2000., 291: "Littrow, Leo von, landscape painter, marine painter, 17. 3. 1860 Triest, 1. before 1929«; ULRICH THIEME, FELIX BECKER, »Littrow, Leo von", Allgemeines Lexikon der bildenden Künstler von der Antike bis zur Gegenwart, Bd. 23, E. A. Seemann, Leipzig, 1929.: "Littrow, Leo von, Landschafts- u. Marine-Maler in Abbazia, ${ }^{\star}$ 17. 3. 1860. Triest, Schüler von Jean d'Alheim in Paris." Kao godine rođenja navodi se i 1857.: GIANNI STELLI (bilj. 3), 59. MARINA BARIČEVIĆ u publikaciji Zrcalna slika: Opatija u djelima likovnih umjetnika, Opatija, 2005., prihvaća kao godinu rođenja 1857. (podatak na str. 12). No, najvjerojatnije je rođena 1855. ili 1856. Dokument o njezinoj smrti, pohranjen u Državnom arhivu u Rijeci, kao godinu rođenja navodi 1856., no poslije je prekrižena i upisana 1855. U knjizi umrlih u Voloskom-Opatiji Atti di morte, Parte 1, njezina je smrt upisana pred svjedocima istog dana, 11. svibnja 1925., a umjesto godine rođenja upisana je dob: »Leontina Littrow di anni sessanta nove«, što znači da je rođena 1856.

14 O poznanstvima i druženjima s nekima od njih imamo sačuvane zapise, a o drugima se može zaključivati posredno, po Leontininim slikama koje su posjedovale obitelji Meynier i Simonić.

15 Pouzdano je da krajem 1883. obitelj Littrow živi u Rijeci i da otac još 1889. godine sudjeluje u ispitima za buduće časnike trgovačke mornarice. Sele vjerojatno poslije sredine osamdesetih. Usp. -, Ein Winterquartier, Wiener Zeitung, 21. prosinca 1883., 1-2.

16 Tih su godina prometne veze već bitno ubrzane. Rijeka i Opatija od ranih sedamdesetih imaju željezničku vezu s Bečom (željeznička stanica Opatija - Matulji), do kojeg se u to doba već dolazi za svega trinaest ili četrnaest sati. Otprije već postoje brojne dužobalne parobrodarske linije koje Kvarner povezuju s Trstom, obližnjim otocima i jugom Jadrana, a početkom osamdesetih osnovano je parobrodarsko društvo »Adria « koje Rijeku redovitim linijama povezuje sa zapadnoeuropskim i britanskim lukama.

17 Danas su te zgrade na adresi Ulica Miroslava Krleže 3 i 5 (nekad Stubište Tomaševac). Nakon Heinrichove smrti, vlasnik te kuće postaje obiteljski prijatelj, tvorničar Robert Whitehead. BORIS ZAKOŠEK, Opatijski album: dugo stoljeće jednog svjetskog lječilišta, Državni arhiv u Rijeci, Rijeka, 2005., 234.

18 GIANNI STELLI (bilj. 3), 58; BORIS ZAKOŠEK (bilj. 17), 234.

19 -, Mostra di quadri, Leo de Littrow, Villa Angiolina, La bilancia, XXVI/45 (24. veljače 1893.), 2.

20 U Državnom arhivu u Rijeci sačuvan je njezin popratni dopis od 4. srpnja 1901. i nacrti paviljona.

21 Nachlass Gräfin Alice Hoyos, Wien, IV., Plösslgasse Nr. 13, Wien, 4. bis 7. Marz 1936.; 103. Kunst-auktion von S. Kende, Wien, I., Rotenturmgasse 
Nr. 14, Wien, 1936. U kataloškom popisu jest devet ulja na platnu i jedno na kartonu: Motiv aus dem Süden, Segelschiff, Zwei Segelschiffe, Baumstudie bei Wasser, Motiv aus Marokko, Zwei Gegenstücke. Segelschieffe, Motiv aus Italien. Durchblick auf Stadt und Hafenszene, Zwei Gegenstücke. Südliche Landschaft u. pflügend. Ochsengespann, Segelschiffe i Motiv aus Abbazia.

22 LIDIJA NIKOČEVIĆ, Iz etnološkog mraka: austrijski etnografski tekstovi o Istri s kraja 19. i početka 20. stoljeća, Zavičajna naklada "Žakan Juri«, Pula, 2008., 97-124.

23 -, Vorträge über Dalmatien, Wiener Montags-Journal, 30. prosinca 1907., 5. Na prijelazu stoljeća u Opatiji je živio i njemački slikar Georg Conraeder (1838.-1911.), portretist i slikar historijskih i alegorijskih kompozicija. I on se zainteresirao za aktualne folklorne teme i naslikao Dalmatinca s crvenom kapom u kićenoj odori (slika u zbirci Muzeja grada Rijeke).

24 NATALIE BRUCK-AUFFENBERG, Dalmatien und seine Volkskunst: Muster und Kunsttechniken aus altem Volks- u. Kirchengebrauch. Spitzen, Stickarbeit, Teppichweberei, Schmuck, Trachten u. Gebrauchsgegenstände der Dalmatiner, Kunstverlag Anton Schroll \& Co., Wien, 1911.; BRANKA VOJNOVIĆ TRAŽIVUK, Dalmatinska narodna umjetnost u AustroUgarskoj Monarhiji početkom 20. stoljeća, Studia ethnologica Croatica, 18 (2006.), 281-298.

25 LIDIJA NIKOČEVIĆ (bilj. 22), 109.

26 -, Notizen. Aus Abbazia, Kikeriki, 16 (21. travnja 1912.), 8.

27 BOETTICHER FRIEDRICH, "Littrow, Leo«, Malerwerke des Neunzehnten Jahrhunderts: Beitrag zur Kunstgeschichte, Bd. I, Boetticher Verlag, Dresden, 1891. (1893.), 887; H. T., Art Centres. London, The Artist. An Illustrated Monthly Record of Arts, Crafts and Industries, 25/235 (1899.), 157-158; E. BÉNÉZIT, Dictionnaire critique et documentaire des peintres, sculpteurs, graveurs de tous le temps et de tous les pays, Vol. 1, Ernest Gründ, Paris, 1924.

28 Blouin Artinfo, URL: http://www.blouinartinfo.com/artists/55358-jean-dalheim\#load (8. 9. 2016.).

29 Bonhams, URL: http://www.bonhams.com/auctions/14219/lot/24/ (8. 9. 2016.). Slikarica je i njegova žena Alexandra-Alexandrina Limosin d'Alheim (Puschkina, rođena u Moskvi oko 1850.), koja osim portreta i cvijeća, slika i naturalističke prizore poput slike Prodavačica riba ili Žena trgovca ribom.

30 Vijesti o njemu vrlo su škrte, no podosta dobar uvid u njegov rad i umjetnički razvoj daju slike objavljene na mrežnim stranicama aukcijskih kuća i trgovaca umjetninama.

31 ULRICH THIEME, FELIX BECKER (bilj. 13).

32 D’Alheim izlaže na pariškom Salonu 1866., 1875. i 1884., a na samostalnoj izložbi 1884. prikazuje osamdeset i dvije slike s motivima Napulja, Venecije i Caprija. E. BÉNÉZIT (bilj. 27); AMIT, Fine Art \& Photography Services, URL: http://www.amitfineart.com/jean\%20dalheim. htm (5. 4. 2016.).

33 Jean d'Alheim, Un e rue de Raguse, Musée d'Art d'Archéologie et de Sciences Naturelles à Troyes, inv. br. 07.2.2 - Joconde. Portail des Collections des Musées de France, URL: www.culture.gouv.fr/public/mistral/ joconde_fr?ACTION=CHER (3. 4. 2016.).

34 Panorama Rijeke s Trsata čuva se u zbirci Muzeja grada Rijeke. Art. com, URL: http://www.art.com/gallery/id--a803833/jean-d-alheim-posters.htm (8. 9. 2016.).

35 Samo se malobrojna njezina djela čuvaju u javnim zbirkama: Muzej grada Rijeke, Wien Museum i Belvedere u Beču, Pomorski muzej u Piranu i Narodna galerija u Ljubljani. Sva ostala djela u privatnim su zbirkama. Nekoliko se poznatih radova nalazi u Rijeci i Opatiji, no većina u Beču i Austriji, te su dostupna jedino u fotografskim reprodukcijama sačuvanim u arhivu bečkih aukcijskih kuća i trgovaca umjetninama Dorotheum, Im Kinsky, Galerie Kolhammer \& Mahringer, Galerie Kovacek \& Zetter, Galerie bei der Albertina i Kunsthandel Widder. Neke su od slika dostupne i na internetu (Artnet).

$36 \mathrm{Na}$ osnovi pojedinih slika kao i na osnovi popisa radova objavljenih u katalozima, naročito katalozima samostalnih izložbi, može se utvrditi da prvo slika Veneciju i Lagunu te opatijsku okolicu.
37 Popis radova sastavljen je na osnovi dostupnih novinskih napisa i kataloga izložbi, vidjeti bilj. 64 .

38 GEORGE LOUIS FABER, The Fisheries of the Adriatic and the Fish thereof: A report of the Austro-Hungarian sea-fisheries, with a detailed description of the marine fauna of the Adriatic Gulf. With Eighteen Woodcut illustrations after drawings by Leo Littrow, and numerous engravings on stone, Bernard Quatrix, London, 1883. Primjerak ove knjige nalazi se u knjižnici Centra za povijesna istraživanja u Rovinju - Centro di Ricerche Storiche Rovigno. George Louis Faber (1843. - oko 1911.), konzul od 1876. sve do uoči Prvoga svjetskog rata. Faber je blizak austrijskim vladinim krugovima, te početkom osamdesetih boravi u Beču i sudjeluje u izradi zakona o ribarstvu. Upravo u to vrijeme piše i svoju knjigu. Vidjeti: IRVIN LUKEŽIĆ, Povijest riječkih konzulata, Adamić, Rijeka, 2004., 127-133.

39 U predgovoru knjige GEORGE LOUIS FABER (bilj. 38) zapisano je "table i gravure doprinijet će umnogome zanimanju za ovu knjigu. Izrađene su prema crtežima koje zahvaljujem prijateljici Leo Littrow. One govore same za sebe (datirano: Fiume, September 30th, 1882)« (preveo E. D.).

40 GEORGE GISSING, By the Ionian Sea: Notes of a Ramble in Southern Italy, with eight illustrations in color by Leo de Littrow and others in black and white, Chapman and Hall, London, 1901.

41 Sliku Volosca nel 1882. objavio je Luigi Maria Torcoletti u Tarsatica ed i primordi di Fiume, Palermo, 1950., 303, sl. 77. Za sliku, objavljenu u crno-bijeloj reprodukciji, navedeno je da je u vlasništvu barunice Luise Klein de Wisenberg (ili Wesenberg?). Nije poznata njezina kasnija sudbina. Među ranim su Leontininim radovima i slike koje su svojedobno bile u posjedu obitelji Meynier, vlasnika Tvornice papira Smith \& Meynier, Dražica (Ribarska lučica u Slatini, ulje na platnu, $56 \times 94 \mathrm{~cm}$ ) i Venecija - Chioggia (Venecijansko predgrade, ulje na platnu, $56 \times 98 \mathrm{~cm}$ ); obje su u zbirci Muzeja grada Rijeke.

42 Ribarska lučica u Slatini (ili u Voloskom), ulje na platnu $56 \times 94 \mathrm{~cm}$, sign. desno dolje: Leo Littrow; Venecijansko predgrađe, $56 \times 98 \mathrm{~cm}$, sign. desno dolje: Leo Littrow. Slike iz ostavštine riječke obitelji Meynier u zbirci su Muzeja grada Rijeke.

43 ERIKA OEHRING, Voyages Pittoresques: Bilder von der Osterreichischen Riviera, u: Österreichische Riviera, Wien entdeckt das Meer, katalog izložbe, (ur.) Christian Rapp, Nadia Rapp-Wimberger, Wien Museum, Czernin Verlag, Wien, 2013., 24-43.

44 LUDWIG SALVATOR, Löse Blatter aus Abbazia, Wien, 1886.; LUDWIG SALVATOR, Jahtom duž hrvatske obale (1870.-1910.), Hrvatski zapisnik, Hannover-Čakovec, 1998.

45 BERISLAV VALUŠEK, Stephanie Glax: (1876.-1952.), katalog izložbe, Umjetnički paviljon »Juraj Šporer«, Opatija, 28. 9. - 28. 10. 2004., 2004.

46 MARTIN SUPPAN, RUPERT FEUCHTMÜLLER (bilj. 2), 291, 313315,372 .

47 ERIKA OEHRING (bilj. 43), 38.

48 Pralje na obali $u$ Opatiji Olge Wisinger-Florian objavljene su u: JOHANNES SACHSLEHNER, Abbazia, K. u. k. Sehnsuchtsort an der Adria, Styria regional, Carinthia, Wien-Graz-Klagenfurt, 2011., 13.

49 ERIKA OEHRING (bilj. 43), 38.

50 GRISELDA POLLOCK, Vision and Difference: Feminity, Feminism and the Histories of Art, Routledge, London, 1988.

51 ERIKA OEHRING (bilj. 43), 38. Autorica tvrdi da je Leontine motiv preuzela od Olge, no poneka rana Leontinina slika djevojke na terasi, u žuto-smeđe-zelenim tonovima, svjedoči u njezinu korist. Slika Park in Abbazia, ulje na kartonu, $50 \times 36,5 \mathrm{~cm}$, signirana inicijalima O. W. F., sliči Leontininim slikama iz opatijskog parka. Jedan od prizora iz opatijskog parka, Südliche Parklandschaft, ulje na platnu, $105 \times 125,6 \mathrm{~cm}$, pripisuje se njihovu zajedničkom radu. Artnet, URL: http://www.artnet. com/artists/lea-leonie-von-littrow-and-olga-wisinger-florian/sudlicheparklandshaft. (8. 9. 2016.).

52 ERIKA OEHRING (bilj. 43), 24-43, 238-239. U katalogu su na str. 239 jedna pored druge objavljene dvije vrlo slične varijante Leontinine i Olgine djevojke pod pergolom; jedna pod nazivom $\mathrm{Na}$ jutarnjem suncu 
(In der Morgensonne, privatno vlasništvo, oko 1890.), druga pod nazivom Na večernjem suncu (In der Abendsonne, Galerie Kovacek \& Zetter, oko 1890.).

53 Auf der Mole in Abbazia. Na slici dolje lijevo upisano: »Drei Wochen in Abbazia. Feb. 1892«, ulje na dasci, 36,8 ×57,8 cm, sign. desno dolje: L. L. Privatno vlasništvo, Beč.

54 ERIKA OEHRING (bilj. 43), 39, 238. Mein Maleratelier in Abbazia, ulje na platnu, $64,5 \times 77,5 \mathrm{~cm}$, Wien Museum, Inv. Nr. 237.083.; Artnet, URL: http:/www.artnet.com/artists/leontine-lea-von-littrow/im-atelier_ggwb-YDoO37qHKP_WP9YQ2 (8. 9. 2016.); Im Atelier, ulje na platnu, $45,4 \times 38,5 \mathrm{~cm}$, privatno vlasništvo.

55 Pall Mall Gazette, 2. studenoga 1896., 3.

56 View in the Alcove at the Further End of the Continental Gallery, kata$\log$ izložbe, London, 1897.; Exhibition of pictures: the islands of the Adriatic and views on the Austrian Riviera, by Leo de Littrow, katalog izložbe, London, 1987.: 1. Street at Arbe, Dalmatia, 2. Ditto, 3. Girl at the Well, Abbazia, 4. A Coast at Cherso, 5. A Well at Abbazia, 6. A Pergola at Abbazia, 7. Well under a Pergola, Abbazia, 8. A Court at Arbe, 9. Court at Arbe, 10. Pergola at Abbazia, 11. Pergola in my Garden, 12. Court at Arbe, 13. Street at Cherso, 14. View of Arbe, Dalmatia, 15. Among the Ruins, Arbe, 16. Old Wals of Veglia, 17. Riva Draga, near Abbazia, 18. Porta Pisana, Veglia, 19. A Bit of Veglia, 20. Well at Draga, 21. Harbour of Veglia, 22. Campo Porta Pisana (Veglia), 23. Staircase in Garden, Villa Angiolina, residence of the German Emperor, 24. Riva Draga, 25. Seashore at Draga, Coast of Istria (napisano je Ischia, op. a.), 26. Garden at Abbazia, 27. On the High Road, Abbazia, 28. The Shore, Island of Veglia, 29. Rainy Morning, Draga, 30. Fishing Village near Lovrana, 31. Street in Lovrana, 32. Fishing Boats, Abbazia, 33. Sketch at Draga, 34. Sketch at Draga, 35. Afternoon at Draga, 36. Pier at Ika, near Abbazia, 37. Kitchen at Abbazia, 38. Ditto, 39. Fishing Nets, Draga, 40. Mending Nets at Draga, 41. Study at Veglia, 42. At Lovrana, 43. Washing at Draga.

57 H. T., The Artist (bilj. 27). Autor prikaza njezine londonske izložbe neodređeno kaže: "She studied in Paris and Munich, if we mistake not, but says nature has been has best teacher, and she always paints with the blue heavens for her roof and surrounded only by the still primitive and picturesque peasant of the isles she loved so well ..."

58 Nachlass Gräfin Alice Hoyos, Wien (bilj. 21). Među Leontininim slikama u grofičinoj zbirci nalazila se i slika Motiv aus Marokko. Velike aukcijske kuće u Londonu na svojim dražbama nude pokoju sliku Leo von Littrow koje se uglavnom povezuju s Italijom. Sotheby's je imao Italian street scene koja je zapravo Ulica na Rabu, kao i druga slika pod nazivom Sunshine at Arbe. Christie's je prodao A sunny day on the Amalfi coast, no zapravo je riječ o Mošćeničkoj Dragi. Vjerojatno su te slike bile izložene u Continental Gallery između 1897. i 1899. Neobično je i da nije slikala prizore iz Beča, Münchena, Pariza i Londona iako je u nekima od tih gradova - u Beču - češće boravila.

59 GEORGE GISSING (bilj. 40); table: Squillace; Bridge at Taranto; Old Taranto, mare piccolo; Fishing boats, Taranto; Temple at Metapontum; Lacinian Promontory; Crotone, from the south; Crotone, from the hills behind; Reggio.

60 PIERRE COUSTILLAS, The Heroic Life of George Gissing, Part III: 1897-1903, Pickering \& Chatto, London-New York, 2012., 193-194: »They don't seem to me very good.« Gissing je u svom dnevniku kada su mu sredinom veljače 1901. godine poslali skice u ulju zapisao: »but I dare say they will be pleasing in the book «. DANIELE CRISTOFARO, George Gissing: Il viaggio desiderato (Calabria 1897), Luigi Pellegrini Editore, Cosenza, 2005., 67; JOHN DOZIER GORDAN, George Gissing, 1857-1903: An exhibition from the Berg Collection, New York Public Library, New York, 1954.

61 Impresionističke ilustracije u boji Leo von Littrow i Gissingove crno-bijele dobro su prihvaćene i dobile su pohvale. Vidjeti: PIERRE COUSTILLAS (bilj. 60), 193-194.

62 Pogled sa Suska na Lošinj, ulje na kartonu, visina 34,5 × širina 47,5 $\mathrm{cm}$, nesignirano i nedatirano. Na poleđini slike u gornjem lijevom uglu rukom je upisano: Piny Littrow, Leo Littrow, San Sego - Lussin, Jan 1908. Vlasništvo Željka Silića, Rijeka.

63 BOETTICHER FRIEDRICH (bilj. 27), 886.
64 Katalozi izložbi: Katalog der Kunst-Ausstellung im Künstlerhause Wien, katalog izložbe, Wien, 1884. (9. 11. 1884.), Kat. Nr. 106.: Littrow Leo in Fiume. Venetianischer Canal (verkäuflich); Katalog der XV. JahresAusstellung in Wien, Künstlerhaus, katalog izložbe, Wien, 1885. (21. 3. 1885.), Kat. Nr. 120.: Leo Littrow, Venezianische Fischerboote; Katalog der XVII. Jahres-Ausstellung in Wien Künstlerhaus, katalog izložbe, Wien, 1887. (2. 4. 1887.), Kat. Nr. 12.: Littrow Leo in Fiume, Dolce far niente (500 fl); Katalog der Kunst-Ausstellung im Künstlerhause Wien, katalog izložbe, Wien, 1894. (1. 7. 1894.), Kat. Nr. 16.: Littrow Leo in Fiume, Oelgemälde. Sturm an der Küste von Istrien (verkäuflich); XXXVII. Ausstellung der Vereinigung Bildender Künstler Österreichs Secession, Wien - I. Ausstellung der Vereinigung Bildender Künstlerinnen Österreichs. Die Kunst der Frau, Novemb. - Dezemb. 1910, katalog izložbe, Wien, 1910.

Novinski članci: -, Die Internationale Kunstausstellung, III Österreichische Malerei, Neue Freie Presse, 18. travnja 1882., 4; -, Kunst-Nachrichten, Östereichische Kunst-Chronik, 27. prosinca 1884., 1066; -, KunstNachrichten, Österreichische Kunst-Chronik, 3. siječnja 1885., 11; -, Die XVI. Jahresausstellung im Künstlerhause, Österreichische Kunst-Chronik, 10. travnja 1866., 322; -, Internationale Skizzen Austelung für Stryi und Lisko, Catalog, Österreichische Kunst-Chronik, 22. svibnja 1886., 437; -, Jahres-Ausstellung in Wiener Künstlerhause, Wiener Zeitung, 9. svibnja 1896., 4; -, Salon Pisko, Aus der Collectivausstellungen, Österreichische Illustrierte Zeitung, 2. travnja 1899., 8; -, Acht Künstlerinnen und ihre Gäste, Salon Pisko, Kunst, Wiener Salonblatt, 17. ožujka 1906., 18.

65 BOETTICHER FRIEDRICH (bilj. 27), 887; -, Prager Kunstausstellung, Juli 1891, Prager Tagblatt, 4. srpnja 1891., 1-2; -, Künstlerhause, Salzburger Volksblatt, 189 (22. kolovoza 1891.), 3; Jahresausstellung von Kunstwerken aller Nationen im. Königl. Glaspalaste. 1. Juli bis Ende Oktober, katalog izložbe, München, 1893.; Münchener Jahresausstellung 1903, Glaspalast, katalog izložbe, Verlag der Münchener Künstlergenossenschaft, München, 1903.; -, Gesellschaft der Kunstfreunde Czernowitz [Austellung am Rudolfsplatz], Bukowinaer Rundschau, 19. lipnja 1906., 3; -, Gesellschaft der Knnstfreunde (Verlosung), Czernowitzer Allgemeine Zeitung, 732 (17. lipnja 1906.), 4; -, Kunstaustellung Klagenfurt, Grazer Tagblatt, 2. ožujka 1907., 12; Catalogo generale della Prima esposizione provinciale istriana. V. Mostra di belle arti, scienze e lettere Maggio Settembre, Capodistria, katalog izložbe, Koper, 1910.

66 K. L. NICHOLS, Austrian Women Painters: 1893 Chicago World's Fair and Exposition, URL: http://arcadiasystems.org/academia/cassatt10c. html (2016.).

67 -, The Dalmatian artists' exhibition in "Elysia «, List of works of art exhibited, u: Imp. [Imperial] Royal Austrian exhibition. London 1906, Earls Court, katalog izložbe, London, 1906., 131, URL: https://archive. org/details/improyalaustrian00urba (8. 9. 2016.).

68 The Bristol Mercury, 12. travnja 1886., 3.

69 Nooks and corners of the Austrian Riviera and the Adriatic sea, katalog izložbe, Continental Gallery, London, 1896.

70 -, The Continental Gallery, The Morning Post, 28. studenoga 1896., 2 .

71 Pall Mall Gazette, 2. studenoga 1896., 3.

72 Lloyd's Weekly Newspaper, 6. prosinca 1896., 10.

73 South Wales Daily News, 2. prosinca 1897., 5.

74 Reynolds's Newspaper Sunday, 5. prosinca 1897., 4.

75 The Glasgow Herald, 6. prosinca 1897., 9.

76 -, World of Art, The Glasgow Herald, 22. veljače 1897., 7.

77 -, Prince of Wales visits de Littrow exhibition, Morning Post, 7. veljače 1898., 6.

78 -, Pittura, La bilancia, 28. prosinca 1896., 2.

79 -, Theater- und Kustnachrichten. [Aus London...], Neue Frei Presse. Morgenblatt, 12547 (29. srpnja 1899.), 6.

80 -, Pictureland, St. Jame's Gazette, 20. prosinca 1904., 18.

81 -, Kunstausstellung der Künstlercolonie "Abbazia«, Grazer Tagblatt: Deutsche Stimmen, Beilage zu Nr. 116 des Grazer Tagblatt, 27. travnja 1900., 9; -, Esposizione artistica in Abbazia, La bilancia, 23. rujna 1901., 2. -, Esposizione artistica in Abbazia, La bilancia, 25. rujna 1901. i 26. 
rujna 1901., 2. Künstler-Colonie Abbazia. III. Kunstausstellung 1902., katalog izložbe, Buchdruckerei V. Tomičić i dr., Abbazia, 1902.

82 -, Esposizione artistica in Abbazia, La bilancia, 25. rujna 1901., 2.

83 JOHANNES SACHSLEHNER (bilj. 48), 154-155; -, Notizen. Aus Abazzia, Kikeriki, 16 (21. travnja 1912.), 8.

84 Kollektiv-Ausstellung Leo v. Littrow, Galerie Miethke, Wien I. Dorotheergasse Nr. 11, 1-30. Mai 1914, Wien, 1914.

85 Elenco delle opere esposte alla esposizione artistica organizzata nelle sale della Villa arciducale, katalog izložbe, Fiume - Natale 1916.; Elenco delle opere esposte all' esposizione artistica organizzata nelle sale della Villa arciducale, katalog izložbe, Fiume Maggio 1917.

86 N. B., L'esposizione d’arte, La bilancia, 7. svibnja 1917., 2.

87 -, L'esposizione di quadri pro scolari poveri: Scuola elementare maschile, Fiume, La bilancia, 27. ožujka 1918., 1-2.

88 MIRISA KATIĆ, $O$ »fenomenu« zadarskoga ženskog slikarstva u vrijeme druge austrijske uprave, Metodički obzori: časopis za odgojno-obrazovnu teoriju i praksu, 9/19 (1) (2014.), 105-114. Leontinini se radovi na austrijskoj izložbi u Londonu susreću s radovima vršnjakinje Antoniette Bogdanovich (Bogdanović), udane Cettineo (1857.-1941.), koja je radila u Beču i Trstu, te među ostalim, naslikala i cara Franju Josipa, a slikala je i na drugim europskim dvorovima.

\section{REFERENCES}

-, Acht Künstlerinnen und ihre Gäste, Salon Pisko, Kunst, Wiener Salonblatt, 17 March 1906, 18.

Alexandra Limosin-d'Alheim (neé Pushkina), c. 1850, Bonhams, URL: http://www.bonhams.com/auctions/14219/lot/24/ (08/09/16).

MARINA BARIČEVIĆ, Zrcalna slika: Opatija u djelima likovnih umjetnika, Opatija, 2005.

E. BÉNÉZIT, Dictionnaire critique et documentaire des peintres, sculpteurs, graveurs de tous le temps et de tous les pays, Vol. 1, Ernest Gründ, Paris, 1924.

E. BÉNÉZIT, "Littrow, Leo von", Dictionary of Artists, Vol. 9, Oxford, 2006, 1127.

The Bristol Mercury, 12 April 1886, 3.

NATALIE BRUCK-AUFFENBERG, Dalmatien und seine Volkskunst: Muster und Kunsttechniken aus altem Volks- u. Kirchengebrauch. Spitzen, Stickarbeit, Teppichweberei, Schmuck, Trachten u. Gebrauchsgegenstände der Dalmatiner, Kunstverlag Anton Schroll \& Co., Wien, 1911.

Catalogo generale della Prima esposizione provinciale istriana. V. Mostra di belle arti, scienze e lettere Maggio - Settembre, Capodistria, exhibition catalogue, Koper, 1910.

-, The Continental Gallery, The Morning Post, 28 November 1896, 2.

PIERRE COUSTILLAS, The Heroic Life of George Gissing, Part III: 18971903, Pickering \& Chatto, London-New York, 2012.

DANIELE CRISTOFARO, George Gissing: Il viaggio desiderato (Calabria 1897), Luigi Pellegrini Editore, Cosenza, 2005.

-, The Dalmatian artists' exhibition in "Elysia", List of works of art exhibited, in: Imp. [Imperial] Royal Austrian exhibition. London 1906, Earls Court, exhibition catalogue, London, 1906, 125-133, URL: https://archive.org/details/improyalaustrian00urba (08/09/16).

XXXVII. Ausstellung der Vereinigung Bildender Künstler Österreichs Secession, Wien - I. Ausstellung der Vereinigung Bildender Künstlerinnen Österreichs. Die Kunst der Frau, Novemb. - Dezemb. 1910, exhibition catalogue, Wien, 1910.

Elenco delle opere esposte alla esposizione artistica organizzata nelle sale della Villa arciducale, exhibition catalogue, Fiume - Natale 1916.

Elenco delle opere esposte all' esposizione artistica organizzata nelle sale della Villa arciducale, exhibition catalogue, Fiume Maggio 1917.

-, Esposizione artistica in Abbazia, La bilancia, 25 September 1901, 2; 26 September 1901, 2.
Exhibition of pictures: The islands of the Adriatic and views on the Austrian Riviera, by Leo de Littrow, exhibition catalogue, London, 1987.

GEORGE LOUIS FABER, The Fisheries of the Adriatic and the Fish thereof: A report of the Austro-Hungarian sea-fisheries, with a detailed description of the marine fauna of the Adriatic Gulf. With Eighteen Woodcut illustrations after drawings by Leo Littrow, and numerous engravings on stone, Bernard Quatrix, London, 1883.

BOETTICHER FRIEDRICH, "Littrow, Leo", Malerwerke des Neunzehnten Jahrhunderts: Beitrag zur Kunstgeschichte, Vol. I, Boetticher Verlag, Dresden, 1891 (1893), 887.

-, Gesellschaft der Knnstfreunde (Verlosung), Czernowitzer Allgemeine Zeitung, 732 (17 June 1906), 4.

-, Gesellschaft der Kunstfreunde Czernowitz [Austellung am Rudolfsplatz], Bukowinaer Rundschau, 19 June 1906, 3.

GEORGE GISSING, By the Ionian Sea: Notes of a Ramble in Southern Italy, with eight illustrations in color by Leo de Littrow and others in black and white, Chapman and Hall, London, 1901.

The Glasgow Herald, 6 December 1897, 9.

JOHN DOZIER GORDAN, George Gissing, 1857-1903: An exhibition from the Berg Collection, New York Public Library, New York, 1954.

H. T., Art Centres. London, The Artist. An Illustrated Monthly Record of Arts, Crafts and Industries, 25/235 (1899), 157-158.

-, Die Internationale Kunstausstellung, III Österreichische Malerei, Neue Freie Presse, 18 April 1882, 4.

-, Internationale Skizzen Austelung für Stryi und Lisko, Catalog, Österreichische Kunst-Chronik, 22 May 1886, 429-438.

-, Jahres-Ausstellung in Wiener Künstlerhause, Wiener Zeitung, 9 May 1896, 4.

Jahresausstellung von Kunstwerken aller Nationen im. Königl. Glaspalaste. 1. Juli bis Ende Oktober, exhibition catalogue, München, 1893.

Jean D' Alheim, Art.com, URL: http://www.art.com/gallery/id--a803833/ jean-d-alheim-posters.htm (08/09/16).

Jean d'Alheim, AMIT, Fine Art \& Photography Services, URL: http:// www.amitfineart.com/jean\%20dalheim.htm (05/04/16).

Jean d'Alheim, Blouin Artinfo, URL: http://www.blouinartinfo.com/ artists/55358-jean-dalheim\#load (08/09/16).

Jean d'Alheim, Un e rue de Raguse, Joconde. Portail des Collections des Musées de France, URL: www.culture.gouv.fr/public/mistral/joconde_fr?ACTION=CHER (03/04/16).

-, K. u. k. Marineoffiziere aus Velden, Veldner Zeitung, 15 December 1986, 37.

Katalog der Kunst-Ausstellung im Künstlerhause Wien, exhibition catalogue, Wien, 1884.

Katalog der Kunst-Ausstellung im Künstlerhause Wien, exhibition catalogue, Wien, 1894.

Katalog der XV. Jahres-Ausstellung in Wien, Künstlerhaus, exhibition catalogue, Wien, 1885.

Katalog der XVII. Jahres-Ausstellung in Wien Künstlerhaus, exhibition catalogue, Wien, 1887.

MIRISA KATIĆ, O “fenomenu” zadarskoga ženskog slikarstva u vrijeme druge austrijske uprave, Metodički obzori: časopis za odgojno-obrazovnu teoriju i praksu, 9/19 (1) (2014), 105-114.

ISO KRŠNJAVI, Zapisci: iza kulisa hrvatske politike, Vol. I-II, Mladost, Zagreb, 1986.

Kollektiv-Ausstellung Leo v. Littrow, Galerie Miethke, Wien I. Dorotheergasse Nr. 11, 1-30. Mai 1914, Wien, 1914.

-, Kunst-Nachrichten, Östereichische Kunst-Chronik, 27 December $1884,1066$.

-, Kunst-Nachrichten, Österreichische Kunst-Chronik, 3 January 1885, 11.

-, Kunstausstellung der Künstlercolonie "Abbazia", Grazer Tagblatt: Deutsche Stimmen, Beilage zu Nr. 116 des Grazer Tagblatt, 27 April 1900, 9.

-, Kunstaustellung Klagenfurt, Grazer Tagblatt, 2 March 1907, 12. 
Künstler-Colonie Abbazia. III. Kunstausstellung 1902., exhibition catalogue, Buchdruckerei V. Tomičić et al., Abbazia, 1902.

-, Künstlerhause, Salzburger Volksblatt, 189 (22 August 1891), 3.

-, La III esposizione della Künstlercolonie in Abbazia, La bilancia, 23 September 1901, 2.

-, L'esposizione di quadri pro scolari poveri: Scuola elementare maschile, Fiume, La bilancia, 27 March 1918, 1-2.

Lea (Leonie) von Littrow and Olga Wisinger-Florian, Artnet, URL: http:// www.artnet.com/artists/lea-leonie-von-littrow-and-olga-wisingerflorian/sudliche-parklandshaft (08/09/16).

Leontine (Lea) von Littrow (Austrian, 1860-1914). Im Atelier, Artnet, URL: http:/www.artnet.com/artists/leontine-lea-von-littrow/im-atelier_ggwb-YDoO37qHKP_WP9YQ2 (08/09/16).

Lloyd's Weekly Newspaper, 6 December 1896, 10.

IRVIN LUKEŽIĆ, Heinrich von Littrow, Fluminensia: časopis za filološka istraživanja, 6/1-2 (1994), 1-14.

IRVIN LUKEŽIĆ, Povijest riječkih konzulata, Adamić, Rijeka, 2004.

IRVIN LUKEŽIĆ, Robert Whitehead: engleski tvorničar torpeda iz Rijeke, Izdavački centar Rijeka, Rijeka, 2010.

-, Mostra di quadri, Leo de Littrow, Villa Angiolina, La bilancia, XXVI/45 (24 February 1893), 2.

Münchener Jahresausstellung 1903, Glaspalast, exhibition catalogue, Verlag der Münchener Künstlergenossenschaft, München, 1903.

MyHeritage Stammbäume, URL: https://www.myheritage.at/research/ collection-1/myheritage (26/02/16).

N. B., Leesposizione d'arte, La bilancia, 7 May 1917, 2.

Nachlass Gräfin Alice Hoyos, Wien, IV., Plösslgasse Nr. 13, Wien, 4. bis 7. Marz 1936.; 103. Kunst-auktion von S. Kende, Wien, I., Rotenturmgasse Nr. 14, Wien, 1936.

K. L. NICHOLS, Austrian Women Painters: 1893 Chicago World's Fair and Exposition, URL: http://arcadiasystems.org/academia/cassatt10 c.html (2016).

LIDIJA NIKOČEVIĆ, Iz etnološkog mraka: austrijski etnografski tekstovi o Istri s kraja 19. i početka 20. stoljeća, Zavičajna naklada "Žakan Juri", Pula, 2008.

Nooks and corners of the Austrian Riviera and the Adriatic sea, exhibition catalogue, Continental Gallery, London, 1896.

-, Notizen. Aus Abbazia, Kikeriki, 16 (21 April 1912), 8.

ERIKA OEHRING, Voyages Pittoresques: Bilder von der Osterreichischen Riviera, in: Österreichische Riviera, Wien entdeckt das Meer, exhibition catalogue, (ed.) Christian Rapp, Nadia Rapp-Wimberger, Wien Museum, Czernin Verlag, Wien, 2013, 24-43.

Pall Mall Gazette, 2 November 1896, 3.

IVAN PEDERIN, Heinrich von Littrow kao pjesnik pomoraca i njemačke manjine u Hrvatskoj, Adrias, 1 (1987), 287-321.

-, Pictureland, St. Jame's Gazette, 20 December 1904, 18.

-, Pittura, La bilancia, 28 December 1896, 2.

GRISELDA POLLOCK, Vision and Difference: Feminity, Feminism and the Histories of Art, Routledge, London, 1988.

-, Prager Kunstausstellung, Juli 1891, Prager Tagblatt, 4 July 1891, 1-2.

-, Prince of Wales visits de Littrow exhibition, Morning Post, 7 February $1898,6$.
Reynolds's Newspaper Sunday, 5 December 1897, 4.

JOHANNES SACHSLEHNER, Abbazia, K. u. k. Sehnsuchtsort an der Adria, Styria regional, Carinthia, Wien-Graz-Klagenfurt, 2011.

-, Salon Pisko, Aus der Collectivausstellungen, Österreichische Illustrierte Zeitung, 2 April 1899, 8.

LUDWIG SALVATOR, Löse Blatter aus Abbazia, Wien, 1886.

LUDWIG SALVATOR, Jahtom duž hrvatske obale (1870.-1910.), Hrvatski zapisnik, Hannover-Čakovec, 1998.

K. G. SAUR, "Littrow, Leo von”, Allgemeines Künstlerlexikon: Bio-bibliographischer Index A-Z, Vol 6, K. G. Saur, München-Leipzig, 2000, 291.

-, Die XVI. Jahresausstellung im Künstlerhause, Österreichische KunstChronik, 10 April 1866, 322.

South Wales Daily News, 2 December 1897, 5.

GIANNI STELLI, Fiume e dintorni nel 1884: Heinrich von Littrow e la prima guida illustrata della Terra di S. Vito, Edizioni Italo Svevo, Trieste, 1995.

MARTIN SUPPAN, RUPERT FEUCHTMÜLLER, Marie Egner: Eine österreichische Stimmungsimpressionistin, Vol. II, Edition Martin Suppan, Wien, 1993.

-, Theater- und Kustnachrichten. [Aus London...], Neue Frei Presse. Morgenblatt, 12547 (29 July 1899), 6.

ULRICH THIEME, FELIX BECKER, "Littrow, Leo von", Allgemeines Lexikon der bildenden Künstler von der Antike bis zur Gegenwart, Vol. 23, E. A. Seemann, Leipzig, 1929.

LUIGI MARIA TORCOLETTI, Tarsatica ed i primordi di Fiume, Palermo, 1950.

BERISLAV VALUŠEK, Stephanie Glax: (1876.-1952.), exhibition catalogue, Umjetnički paviljon “Juraj Šporer”, Opatija, 28 September - 28 October 2004.

View in the Alcove at the Further End of the Continental Gallery, exhibition catalogue, London, 1897.

BRANKA VOJNOVIĆ TRAŽIVUK, Dalmatinska narodna umjetnost $u$ Austro-Ugarskoj Monarhiji početkom 20. stoljeća, Studia ethnologica Croatica, 18 (2006), 281-298.

-, Vorträge über Dalmatien, Wiener Montags-Journal, 30 December 1907, 5.

-, Ein Winterquartier, Wiener Zeitung, 21 December 1883, 1-2.

-, World of Art, The Glasgow Herald, 22 February 1897, 7.

BORIS ZAKOŠEK, Opatijski album: dugo stoljeće jednog svjetskog lječilišta, Državni arhiv u Rijeci, Rijeka, 2005.

\section{ARCHIVAL SOURCES}

Državni arhiv u Rijeci, Atti di morte, Parte 1, Volosko-Opatija: 11. svibnja 1925.

Kriegsarchiv, Wien, Marine/Marine Qualifikation Liste, No 3127 Kriegsarchiv, Wien, K. u. k General Commando zu Agram, 1866. 
Summary

Ervin Dubrović

Leontine Littrow, Woman Painter of Late 19th and Early 20th Century

Leontine Littrow (Trieste, 1855 - Opatija, 1925) was a woman painter who signed her works exclusively as Leo Littrow or by initials L. L. She was also called Lea or Leonie. She belonged to a prominent German family, her father was a sea captain and her grandfather and uncle were astronomers and directors of the Vienna observatory. On her mother's side she descended from the British family Barry who moved to Trieste around 1830 and whose members served as officers in the Austrian navy, two of them as admirals. The artist lived in Rijeka from 1867 until late 1880s, and then in Opatija. She studied painting under Jean d'Alheim, a painter from Paris who travelled to Croatia and painted views of Rijeka, Rab and Dubrovnik. Her artistic development can be traced from early 1880s until early 1920s: during the four decades of her career her work underwent different stylistic changes, from early Romanticist to plein air and Impressionist paintings, and finally expressive and pronouncedly three-dimensional renderings of cliffs and the sea.

Her known oeuvre includes mostly views of Venice and its surrounding landscape, as well as sea and fishing scenes in Rijeka and Opatija such as laundresses on the shore, views, secluded places, small houses and rooftops of Volosko, motifs and views of Ika, Lovran, Mošćenička Draga, Mošćenice and Brsečc, and later of islands of the Kvarner Bay and of Dalmatia. Constant themes of her paintings were also gardens and parks in Opatija, pergolas and gazebos, as well as southern, Mediterranean landscapes with pines, cypresses, palms and agaves. Between 1880 and 1924 Leontine Littrow participated in a series of group and several solo exhibitions, most often in annual Künstlerhaus exhibitions in Vienna from 1880 until the beginning of the $20^{\text {th }}$ century. She also participated in international exhibitions in the Glaspalast in Munich (1893 and 1903) and many other exhibitions in Central Europe and Germany (Prague, Budapest, Klagenfurt, Salzburg, Wroclaw, Chernivtsi, Koper) as well as in Opatija (1893, 1900-1902, 1908 and 1912) and in Rijeka (1916, 1917, 1918 and 1924). She achieved her greatest success in London, where she exhibited in the Royal Academy as early as 1886, and between 1896 and 1899 she held several acknowledged solo exhibitions in the Continental Gallery, praised by the critics for the bright light, freshness and colourism of southern landscapes. News of her success reached Vienna, Rijeka and Opatija. She also participated in the Chicago World's Columbian Exhibition in 1893 in the Austrian women painters' section, as well as in the large Imperial Austrian Exhibition in London in 1906 in the Dalmatian section, alongside Bukovac, Vidović, Meštrović and others. 